\title{
ALGUNAS CONSIDERACIONES SOBRE LA MÚSICA PARA CONJUNTOS INSTRUMENTALES EN EL SIGLO XVII ESPAÑOL ${ }^{1}$
}

\author{
Luis Antonio GONZÁLEZ MARÍN
}

Departamento de Musicología, CSIC

\begin{abstract}
This paper attempts to update some hypothesis and evidences about instrumental composition and performance in seventeenth-century Spain, looking at both the different written documents and the extant musical sources. The existence of parallelisms between the different ecclesiastic, civil ant theatrical music traditions leads to an assimilation of related genres, and brings out some important consequences on performance practice.
\end{abstract}

\section{Resumen}

Este artículo trata de poner al día algunas hipótesis y evidencias sobre la composición y ejecución de música instrumental en España durante el siglo XVII, basándose tanto en testimonios escritos de diversa índole como en las propias fuentes musicales existentes. El establecimiento de paralelismos entre las tradiciones musicales eclesiásticas, civiles y teatrales conduce a una equiparación de géneros afines, y trae consecuencias de interés en lo tocante a la práctica musical.

\section{Introducción}

Este trabajo surge de una serie de preguntas que cuantos nos dedicamos al estudio de la música española del siglo XVII nos hemos planteado alguna vez: ¿Dónde está la música de los ministriles, la música de las «orquestas» de teatro, la música «de cámara»? ¿Por qué aparecen tan pocos restos, en comparación con los vastos repertorios vocales conocidos? ¿Casi todo se ha perdido? ¿O es que realmente la circulación de este tipo de composiciones fue muy escasa en aquel tiempo?

1. Este trabajo se inscribe en el marco de la investigación desarrollada en el Proyecto Coordinado de la DGICYT: "Los instrumentos en la música del barroco en la antigua Corona de Aragón. 02 ARAGÓN" (Departamento de Musicología del CSIC, en coordinación con la Universidad Autónoma de Barcelona). 
Son relativamente numerosos los testimonios que parecen demostrar la existencia de una práctica instrumental habitual en diferentes ámbitos, tanto en las iglesias como en los teatros y en los salones. Sin embargo, el número de piezas para conjunto instrumental producidas en España o por músicos españoles que se conocen hoy es muy reducido. Junto a esto, existe una cierta cantidad de pruebas documentales sobre el conocimiento en España, extendido en algunos ambientes, de música instrumental de origen extranjero (de Italia, Inglaterra, Flandes), que se practicaba regularmente, así como la presencia de instrumentistas y compositores de procedencia diversa (en particular italianos, flamencos e ingleses).

El presente trabajo trata de exponer y documentar algunas hipótesis sobre este problema: la producción española de música para conjuntos instrumentales en el siglo XVII, frente a la producción extranjera que llegaba o que pudo llegar, en los diferentes ámbitos de cultivo de la música (las iglesias, los teatros y la vida civil en general).

\section{Estado de la cuestión y fuentes}

Para comenzar, el número de composiciones estrictamente para conjunto instrumental conocidas en el ámbito español del siglo XVII es extremadamente exiguo. No pretendo ofrecer una lista completa de las piezas conservadas, lo que resulta hoy imposible, dado que todavía no disponemos de una visión total de las fuentes españolas del siglo XVII — numerosos archivos se encuentran todavía sin catalogar, e incluso los hay inexplorados-, de modo que en este elenco, naturalmente provisional, sólo citaré las composiciones que he tenido oportunidad de examinar hasta ahora ${ }^{2}$ : 1) el dúo y el tercio copiados en el libro que Diego Pontac preparó para la imprenta (el volumen manuscrito de 1631 conservado en la Biblioteca de Cataluña) ${ }^{3}$, tal vez no previstos necesariamente para su ejecución instrumental; 2) una obra anónima para instrumento bajo, que posiblemente perdió su acompañamiento, conservada en el Archivo de Música de las Catedrales de Zaragoza ( $E$ : Zac), y que el musicógrafo Gregorio Arciniega atribuyó a Domingo Hernández, compositor zaragozano activo en el primer tercio del XVII (E: Zac, B-41/638) ${ }^{4}$; $)$ un

2. Eduardo López Banzo me dio noticia de algunas piezas halladas en Castilla. Asimismo, Emilio Moreno me informó de una composición de tipo canzona para tiple y bajo conservada en una fuente italiana con la atribución "Patino de Madrid", al parecer de Carlos Patiño. Ante la imposibilidad de estudiarlas antes de presentar este trabajo, omitiré cualquier referencia a las mismas. Tampoco incluyo en la lista los libros de ministriles de la colegiata de Lerma (el primero conservado hoy en la Universidad de Utrecht, 3.L.16, y el segundo en Lerma) estudiados por D. KIRK, "Instrumental music in Lerma, c. 1608", Early Music, XXIII/3, 1995, 393-408, manuscritos que contienen repertorio vocal del siglo XVI desprovisto de textos para ser utilizado por los ministriles.

3. J. López-Calo (Historia de la música española. III. Siglo XVII, Madrid, Alianza, 1983, 224) atribuye estas piezas a Pontac y las considera instrumentales. P. RAmos (La música en la catedral de Granada en la primera mitad del siglo XvII: Diego de Pontac, Granada, Diputación Provincial-Junta de Andalucía, 1994, 273-274) discute la autoría de las mismas, pero nada aclara sobre su condición vocal o instrumental. A pesar de lo arcaizante de su concepción (piezas estrictamente contrapuntísticas sin un acompañamiento continuo), es posible que Pontac considerara un posible uso instrumental de las mismas, como ocurre con los ejemplos de Lorente que luego se citan. Una bibliografía actualizada sobre Pontac se encontrará en A. EzQUERRo, El músico aragonés Diego de Pontac, Zaragoza, Institución Fernando el Católico, 1991, y en el libro citado de P. Ramos.

4. Publicada en L. A. González Marín, "Dos nuevas piezas españolas del siglo XVII para conjunto instrumental", en Nassarre, IX, 2, 1993, 161-170. 
madrigal ${ }^{5}$ anónimo datado en 1671 (E: Zac B-71/1032) ${ }^{6}$; 4) otro madrigal de Juan Pérez Roldán, fechado en 1672 (E: Zac B-10/187) ; 5) una Recercada de dos baxos conservada en el Archivo de la Catedral de $\mathrm{Jaca}^{8}$; 6) la Sonata a 3 de José de Vaquedano (Archivo de la catedral de Santiago de Compostela) ${ }^{9}$; 7) dos Resercadas, una a 2 (fechada en 1692) y otra a 3 , conservadas en la Biblioteca de Cataluña (n. ${ }^{\text {os }} 1212$ y 1213 del Catàlech de Pedrell) ${ }^{10}$; 8) unos bayletes publicados por Romà Escalas bajo el apelativo de baixetes, obras de posible procedencia italiana y fechables ca. 1700 (Biblioteca de Cataluña, Ms. 747/3; Catàlech, $\mathrm{n}^{\circ}$. 1218) ${ }^{11}$; 9) una serie de composiciones anónimas contenidas en el llamado Manuscrito de Jaca (Huesca), que luego describiré, probablemente también de procedencia italiana y de igual fecha; 10) algunas composiciones para clarines, recogidas en uno de los manuscritos de Antonio Martín y Coll, recopilados ya en la primera década del siglo XVIII ${ }^{12}$;1) finalmente, una sinfonía y un minuete de la zarzuela Muerte en amor es la ausencia, de Sebastián Durón (1697 ó 1725; E:Mn M 1365), de los que sólo se conserva el acompañamiento. Podrían incluirse en la lista los pasacalles, introducciones, versos o tocatas de chirimías que preceden o acompañan a un cierto número de composiciones vocales religiosas; pero se trata de composiciones muy breves, algunas de ellas de carácter convencional (los pasacalles), y dependientes de la obra vocal a la que preceden o en la que se insertan. Excluyo deliberadamente de este elenco las obras publicadas de Bartolomé de Selma y de Francisco José de Castro, que en realidad deben considerarse música italiana, así como algunas otras composiciones del ámbito portugués, hispanoamericano y napolitano directamente relacionadas con la práctica musical española (me refiero al Tarambote para dos chirimías y bajo conservado en el Monasterio de Santa Cruz de Coimbra publicado por Brito ${ }^{13}$; las obras tipo canzona conservadas en la Universidad de esta ciudad; el verso para dos chirimías y bajo de Manuel Blasco -Quito, 1684- publicado por Stevenson ${ }^{14}$, o las sinfonías de la ópera El robo de Proserpina, de Filippo Coppola ${ }^{15}$ ).

5. Sobre el término usado en este contexto instrumental, así como sobre posibles características formales, cfr. mi artículo "Aportación al conocimiento de la terminología musical española en el siglo xVII: El Madrigal considerado como composición para instrumentos", en Nassarre, V, 2, 1989, 119-129. Ver también nota 6.

6. Publicado en L. A. González Marín, Música para los ministriles de El Pilar de Zaragoza (1671-1672), vol. I de «Piezas de música», Zaragoza, Institución Fernando el Católico, 1991.

7. Ibid.

8. Desconozco si la obra dispone ya de una signatura definitiva, pues el citado archivo se encuentra en proceso de catalogación. Debo la información y las facilidades para consultar la pieza a Pedro Calahorra Martínez. La pieza ha sido registrada en un CD: «Banchetto musicale», Cuerdas, aunque disímiles, aunadas, Huesca, Arsis-Geaster S.L., 1996 (4110105).

9. La obra fue editada por J. López-CALo, Obras musicales de fray José de Vaquedano Santiago de Compostela, Música en Compostela, 1990. Existe una grabación de la Capela Compostelana, José de Vaquedano, Santiago de Compostela, EDIGAL, 1991 (ECD-70029).

10. La primera de ellas fur publicada por R. Escalas, Resercada, Baixetes, Minuets, Barcelona, Biblioteca de Cataluña, 1974

11. Ibid.

12. Me refiero a las Canciones diversas a dos clarines y otra de un clarín solo, del volumen titulado Huerto ameno de varias flores de música..., copiado en 1708 (E:Mn, M. 1359, 561-582). Han sido publicadas por A. BACIERO, Nueva Biblioteca Española de música de teclado. Volumen VII, Madrid, Unión Musical Española, 1984.

13. M. C. DE Brito, Vilancicos do século XVII do mosteiro de Santa Cruz de Coimbra, Portugalia Musica XLIII, Lisboa, Fundaçao Calouste Gulbenkian, 1983.

14. R, Stevenson, "Hispanic American Music Treasury", en Inter-American Music Review, VI, $2,1985$.

15. L. A. González Marín, F. Coppola-M. García Bustamante: "El robo de Proserpina" (1678), Barcelona, Consejo Superior de Investigaciones Científicas, 1996. 
Por lo que se refiere a las obras vocales que incluyen partes instrumentales, la nómina sería muy larga. Baste citar las ediciones de este tipo de composiciones realizadas por Juan Bautista Guzmán, Miguel Querol, Francesc Bonastre, Josep Pavia, José Climent, Robert Stevenson y otros, o algunas que yo mismo he editado (véase la bibliografía), así como los ejemplos inéditos que presento más abajo.

Sobre la materia se han publicado algunas interesantes reflexiones y noticias, debidas principalmente a Bonastre, López-Calo, Martín Moreno y González Valle, así como a Luis Robledo y Louise Stein. Fuera de la investigación sobre la música española, he hallado nuevos puntos de vista en algunas publicaciones de Georgiades, Carse, Newman y Bianconi, que se reflejan en la bibliografía de este trabajo.

En cuanto a las fuentes documentales, al margen de las consabidas Actas Capitulares, Libros de Fábrica, etc., que suelen traer noticias sobre músicos, sobre adquisición de instrumentos y de obras musicales, así como sobre ejecuciones de música extraordinarias, es preciso, para abordar repertorios alejados del mundo eclesiástico, adentrarse en los listados de gastos palaciegos, las relaciones de fiestas, los libros de viajeros, etc. En este sentido me ha sido de gran utilidad, entre otras obras, la colección "Fuentes para la historia del teatro en España" de Tamesis Books, dirigida por Shergold y Varey.

Debo citar finalmente los escritos de música práctica de la época que nos ocupa, entre los que he de destacar, aparte del tratado de Cerone (anclado todavía en el siglo XVI), la obra de Andrés Lorente (muy parca en alusiones a lo instrumental, pero reveladora de un importante dato sobre la práctica de ejecutar en los instrumentos obras no propiamente destinadas a ellos), y, muy especialmente, tres tratados cuya redacción o publicación son muy tardías, pero que no por ello dejan de ser de utilidad, por sus alusiones, más o menos encubiertas, a la práctica musical tradicional del siglo XVII. Me refiero a la Escuela música de Pablo Nassarre (1723-1724), al Mapa armónico de Francisco Valls (ca. 1742) y a la Guía para los principiantes de Pere Rabassa (ca. 1724-1738). La obra de Nassarre fue enteramente concebida, y posiblemente redactada en gran parte, en los últimos veinte años del siglo XVII, como parece demostrado por Siemens; Nassarre fue testigo directo de la práctica de este siglo, y es lo que refleja en su escrito, donde sorprende no encontar alusiones a géneros, tipos de composición o instrumentos en boga desde, al menos, comienzos del siglo XVIII (por ejemplo, la cantada, el aria o el oboe, que no se mencionan). Valls, por lo demás mucho más acorde con su tiempo, establece frecuentes comparaciones entre la música de actualidad y la música antigua, que, para el autor catalán, abarca todo el siglo anterior, hasta los inicios del XVIII (así, Valls considera a Corelli como uno de los meritorios compositores antiguos extranjeros). Rabassa, por fechas y por conceptos, se encuentra en un punto intermedio, al menos en lo que a los instrumentos y la música instrumental se refiere.

Antes de desarrollar el tema, quisiera introducir una reflexión de partida dedicada a la producción española de música estrictamente instrumental. En este punto existe una cierta contradicción entre Nassarre y Valls. Para el darocense, la composición de sinfonías (que para él son las piezas para conjunto instrumental en general), es un género poco usual en España: «En otras Naciones se practica más que en España esta especie de música, y especialmente en la Italia; 
practicando en ella, mucha variedad de ayres, lo qual haze la composición más armoniosa, y más deleytable. Unas vezes varían al ayre con la mudança de la señal indicial, ya siendo un período de compasillo, o otro de proporción, otro de sexquiáltera, \&c. Y aun debaxo de un mismo tiempo, un período hazen muy a espacio, otro muy ayroso, otro no tanto, \&c. y assí las hazen muy deleytables, por razón de esta variedad.» ${ }^{16}$ (Debe tenerse en cuenta que está hablando de dos niveles, el de la composición y el de la interpretación de los signos de aire, que no eran desconocidos en España; en efecto, estas variaciones en la velocidad, dentro de un mismo compás, eran perfectamente conocidas en la música vocal española durante el siglo XVII, y también en algunas composiciones instrumentales conservadas, como, por ejemplo, uno de los madrigales citados). Sin embargo, Valls se lamenta de la superabundancia de composiciones de este tipo, generalmente hechas sin conocimiento ni respeto a las reglas: «En la era presente hay gran cosecha de compositores de Tocatas, sonatas, y symphonías; de las más se puede dezir, que es una composición, que no ata, ni desata, sin cuydar de reglas, ni preceptos; porque qualquiera mediano violinista se mete a compositor de Symphonías... De este estylo no son menestrer exemplares... aviendo tanta copia de unas, y otras obras, puede el compositor recurrir a ellas.» ${ }^{17}$. Tal vez esta discrepancia se deba a la diversidad del entorno en que viven ambos músicos: Nassarre, formado en un núcleo urbano reducido (Daroca), pasa su vida en un convento franciscano de Zaragoza, mientras que Valls ha regido durante años la capilla de la catedral de Barcelona, ciudad que, entre tanto, ha sido capital y corte durante el efímero reinado del archiduque Carlos de Austria, en el transcurso del cual ha podido tener acceso a mucha música extranjera que, sin duda, ha contribuido a renovar la práctica barcelonesa. Influirá no menos la distancia cronológica que separa ambos escritos, que, de ser ciertas las teorías de Siemens, puede rondar los cincuenta años. Pero, además, volviendo al último tercio del siglo XVII, tenemos otro testimonio que completa lo expuesto por Nassarre: Gaspar Sanz, ya en la tercera edición de su Instrucción de música (1674), alude a «sonadas, y conciertos de Biolines que vienen de Italia» ${ }^{18}$ y no menciona obras españolas semejantes. Desconocemos en qué cantidad y con qué frecuencia llegaban esas sonadas y conciertos, hasta qué punto eran imitadas por los compositores españoles y en qué ambientes se difundían (tal vez muchas de ellas llegaran a Zaragoza en la cartera del propio Sanz, que, no lo olvidemos, dedicó su libro al filarmónico Don Juan de Austria, del que luego se hablará), pero parece claro que los receptores de esa música italiana eran instrumentistas de formación española, como demuestra el hecho de que encontraran dificultad para tocar obras con muchos sostenidos o bemoles ${ }^{19}$.

16. P. NASSARRE, Escuela música según la práctica moderna, Zaragoza, Herederos de Diego de Larumbe, 1724 y Manuel Román, 1723 (ed. facsímil: Zaragoza, Institución Fernando el Católico, 1980), II, 311.

17. F. Valls, Mapa armónico práctico, Barcelona, 1742 (cito siempre por el ejemplar de la Biblioteca de la Universidad de Barcelona, Ms. 783), ff. 193r-193v.

18. G. SANZ, Instrucción de música sobre la guitarra española, Zaragoza, Herederos de Diego Dormer, 1674 (ed. facsímil: Zaragoza, Institución Fernando el Católico, 1979), f. 31v.

19. Sobre Gaspar Sanz, cfr. mi articulo "Sanz y Celma, Gaspar" en Diccionario de la Música Española e Hispanoamericana, Madrid, ICCMU (en prensa), donde se discuten aspectos como su presencia real en Italia y su formación musical. 


\section{La música para conjuntos instrumentales en el siglo XVII español}

Tradicionalmente separamos dos ámbitos para el estudio de la música en el siglo XVIr: lo eclesiástico y lo civil. Caben y son necesarias sucesivas subdivisiones: así, lo litúrgico y lo no litúrgico, en el ámbito de las iglesias; lo propiamente cortesano o áulico, lo festivo, lo camerístico, en el ámbito civil. Finalmente, el fenómeno teatral afecta en mayor o menor medida a ambos campos (los dos polos son la comedia y el auto sacramental). La música para diferentes conjuntos instrumentales está documentada, y en algunos casos ratificada por la existencia de composiciones conservadas, en todos esos terrenos. Sin detenernos, por ser innecesario, en una categorización de las familias de instrumentos y su desarrollo y uso en el siglo XVII, y conscientes de que toda consideración en esta materia ha de ser sometida a revisión, por nuestro conocimiento todavía incompleto de las fuentes musicales españolas de la época, podemos, sin embargo, establecer una serie de relaciones, por la frecuenia de su uso, entre determinados instrumentos y ciertos ámbitos. En este trabajo me centraré particularmente en la música de iglesia, aunque dedicaré algunas consideraciones a los otros ámbitos. En cualquier caso, no me referiré específicamente a los instrumentos destinados a realizar el acompañamiento, como órgano, clave, arpa, guitarra, tiorba, etc., sobre los que próximamente presentaré otro trabajo ${ }^{20}$.

\section{La música de iglesia}

En el terreno eclesiástico, además de la confirmación documentral (libros de fábrica, actas capitulares de diferentes catedrales y colegiatas), se conserva una gran cantidad de composiciones vocales con intervención más o menos importante de agrupaciones instrumentales, y, junto a ello, una muy pequeña cantidad de piezas exclusivamente instrumentales. A pesar de las importantes lagunas citadas, la música de iglesia es la mejor estudiada hasta el presente, y la que más y mejor se ha conservado. Baso mis datos en el estudio directo de un vasto fondo de música del siglo XVII, el Archivo de Música de las Catedrales de Zaragoza ( $E$ : $Z a c)^{21}$, y en la confrontación de esta realidad con lo conservado en otros muchos archivos de la Península, a través de mi trabajo directamente sobre ellos, o de los catálogos publicados.

En la música de iglesia, litúrgica o no, se registra, junto a las voces, un uso relativamente abundante de los instrumentos de viento, por familias de composición convencional (por ejemplo, 2 ó 3 bajoncillos y bajón, 2 ó 3 chirimías y sacabuche, según se trate de coros de ministriles a 4 -lo más tradicional, siguiendo modelos vocales ${ }^{22}$ : TiATeB o TiTiA/TeB-, coros de minis-

20. Sobre el órgano como instrumento de acompañamiento, cfr. L. A. GonZÁlez MARín, "El órgano y el acompañamiento en la música española del Barroco", en Rolde, 58-59, 1991, 45-52. Asimismo, existe un proyecto de Tesis Doctoral, a cargo de Jesús Alonso Yllana, sobre el continuo en España realizado en instrumentos de cuerda pulsada (Madrid, Universidad Autónoma).

21. Véase una somera descripción del mismo en L. A. GonZÁlez Marín, "Fuentes musicales en la Corona de Aragón: archivos y bibliotecas de Zaragoza. El Archivo de Música de las Catedrales de Zaragoza", en Anuario Musical, 49, 1994, 301-304.

22. Utilizo las siguientes iniciales: $\mathrm{T} i=$ tiple; $\mathrm{A}=\mathrm{alto} ; \mathrm{Te}=$ tenor; $\mathrm{B}=$ bajo. 
triles a 3 - lo más avanzado y más puramente instrumental: la estructura en trío TiTiB, sin partes intermedias - o coros formados por una parte vocal y tres ministriles —en estos casos también el concepto puede estar más enraizado en la tradición - por ejemplo, un Te más instrumentos TiAB - o ser más progresivo - por ejemplo, un Ti acompañado por instrumentos TiTiB-) o en agrupaciones «mixtas» establecidas por la costumbre (por ejemplo, corneta, bajoncillo, bajón y sacabuche; o, más raramente, dos flautas y bajón).

La presencia registrada de instrumentos de arco (violines, vihuelas de arco) es muy escasa y a menudo tardía, podría calificarse casi de anecdótica, y, al menos en ciertos lugares, parece deberse a circunstancias particulares. Para el caso zaragozano, E: Zac conserva sólo cuatro composiciones del siglo XVII donde específicamente se requiere el uso de violines, y otras tres donde se requieren vihuelas de arco. En cuanto a las obras con violines, la primera y más antigua es un villancico de Navidad de Pedro Ximénez de Luna, maestro de Santo Domingo de la Calzada que en 1636 concursó a la plaza de maestro de capilla de El Pilar de Zaragoza, sin obtenerla (el vencedor sería Miguel de Aguilar) ${ }^{23}$; de Luna se conserva gran cantidad de composiciones en $E$ : Zac (una de ellas fechada en 1634), algunas de ellas remitidas al maestro Aguilar y al organista Joseph Muniesa. El villancico de Luna (Milagro, milagro, E: Zac B-27/449) presenta una entrada (Ejemplo $1^{24}$ ) en que dialogan dos tiples, uno solo (su acompañamiento se ha perdido) y el otro acompañado por dos violines y bajo, disposición que se repite en las coplas, tras la responsión a 12, en la que los dos violines y el bajo instrumental forman el coro II junto a un tenor. La composición es, por todo ello, novedosa, y, por la similitud de su caligrafía con la de las demás obras de Luna conservadas en el mismo archivo, incluidas aquéllas fechadas que contienen cartas, me inclino a pensar que se trata de una fuente contemporánea al autor, tal vez autógrafa, lo que choca con la información que tenemos sobre la capilla de música de El Pilar, que, a lo que parece, carecía de violines en fechas tan tempranas. Sin embargo, en La Seo está documentada la presencia de un violín entre al menos 1640 y $1642^{25}$.

Las otras tres composiciones con violines conservadas en $E$ : Zac son muy posteriores. Entre 1668 y 1670 se debe datar, por razones que luego expondré, la lamentación Lamed. Matribus suis dixerunt de Joseph Ruiz Samaniego (fl. 1653-1670), para tenor, dos violines y bajo (compuesto éste por un instrumento melódico —bajón o violón-y archilaúd) ${ }^{26}$. De 1671 es el antes citado madrigal negro Ziolo plimo, ola, anónimo, compuesto a dos coros de instrumentos ( 2 bajoncillos, bajón y órgano; 2 violines, violón y arpa). La última de las composiciones, de

23. Véanse algunos datos biográficos de este autor en A. EzQuerro, "Ximénez de Luna, Pedro", Diccionario de la Música Española e Hispanoamericana, Madrid, ICCMU (en prensa).

24. Para la transcripción de estos ejemplos he optado por conservar las claves, compases y tesituras originales, aun siendo consciente de que algunos de ellos (los escritos en claves altas) requieren un transporte, posiblemente a la cuarta inferior, según expresan reiteradamente los tratados españoles.

25. Actas Capitulares de La Seo de Zaragoza, 1640ss., fol.115.

26. Cfr. mis artículos "Lamentaciones" y "Ruiz Samaniego, Joseph" en Diccionario de la Música Española e Hispanoamericana, Madrid, ICCMU (en prensa), así como mi edición de la obra en Las Lamentaciones de Joseph Ruiz. Samaniego, Zaragoza, Institución Fernando el Católico (en prensa).. Esta pieza fue antes publicada por M. Querol (Música Barroca Española. V. Cantatas y Canciones, Barcelona, CSIC, 1973), sometida a algunas manipulaciones (reducción de valores, alteración de los compases, accidentales añadidos) que tergiversan su sentido original. 
Joseph de Cáseda, fechable en los años 90, presenta un carácter mucho más arcaizante: se trata de un motete a 10 , en que un solo violín dialoga con un tiple en el primer coro ${ }^{27}$. Las dos obras centrales, compuestas en el marco de la capilla de música de El Pilar, se sitúan en los años en que el filarmónico Don Juan de Austria se encontraba en Zaragoza. Ruiz Samaniego, que le dedicó varias composiciones y hospedó a algunos de sus músicos, tal vez pudo beneficiarse de dichos contactos, máxime cuando, como sabemos, la capilla de El Pilar no contaba con violinistas de plantilla ${ }^{28}$.

Por lo que se refiere a las piezas con vihuelas de arco conservadas en E:Zac, dos de ellas vienen atribuidas en las respectivas fuentes a fray Manuel Correa, y la otra es anónima. El villancico Tras de un amoroso lance, de fray Manuel Correa sobre un texto de Santa Teresa está compuesto a tres voces (dos tiples y tenor), con acompañamiento, escrito en una sola particella, de «arpa i biguela de arco», y presenta la particularidad de que las partes de tiple se destinan a sendas monjas carmelitas cantoras (Ynés y Vastida), como sucede en otras composiciones del autor, también carmelita $^{29}$. En su villancico a Santo Domingo Esa estrella que ves, destinado a la misma capilla de monjas carmelitas, encontramos una particella de bajo con el siguiente texto: «bajo biguela de arco. Y banjon [sic] grande si le Vbiere», a la vez que, en la parte de tenor, se indica que se tocará con bajoncillo tenor en caso de que la cantora - $\mathrm{D}^{\mathrm{a}}$. Beatriz de Mendoza - no pueda cantar una parte $\tan$ grave $^{30}$. La tercera pieza es un motete anónimo titulado Ecce nunc benedicite (E:Zac B-63/897), a 6 con acompañamiento, en el que el coro I está compuesto por dos tiples y el coro II por un tiple más alto, tenor y dos bajos de vihuela de arco, que intervienen siempre en bloque. Actualmente carecemos de argumentos para aventurar una atribución de la obra o discutir su procedencia.

Es diferente el caso de las Capillas Reales, donde los instrumentos de arco están presentes, al menos para determinadas solemnidades, desde los albores del siglo XVII, aunque no se hayan conservado o encontrado hasta ahora composiciones tan tempranas que lo confirmen. En algunas catedrales se registra también la presencia de instrumentos de arco desde comienzos del siglo, como es el caso de Santiago de Compostela $(1610)^{31}$; lamentablemente, las fuentes musicales que requieren la intervención de dichos instrumentos son siempre mucho más tardías: en el caso de Santiago, hay que esperar a Vaquedano, cuyas Sonata y Lamentación con vigüelas podrían pertenecer a su etapa madrileña ${ }^{32}$. Esto puede explicarse como un problema de conservación

27. Me refiero al motete a San Vicente, San Martín y San Valero Levita Vincentius, a 10 (E:Zac B-92/1383).

28. Datos sobre la relación de Ruiz Samaniego con Don Juan de Austria se encuentran en mi artículo "En la pompa, la gala y la fiesta. Música festiva en tiempos de Joseph Ruiz Samaniego (fl. 1653-1670)", en Rolde, 79-80, 1997, 73-92, así como en la citada voz "Ruiz Samaniego, Joseph" y la edición Las Lamentaciones de Joseph Ruiz Samaniego.

29. Sobre música de Manuel Correa destinada a monjas cantoras, vease mi comunicación "Reflexiones sobre la ejecución vocal en la práctica musical española del siglo xVII", en el IV Congreso de la Sociedad Española de Musicología (Madrid, mayo de 1997), de próxima publicación en Revista de Musicología. Una selección de villancicos de Correa podrá consultarse en la edición de J. V. GonZález Valle en los Monumentos de la Música Española del CSIC (en prensa).

30. Estas dos obras de Manuel Correa han aparecido recientemente en La Seo de Zaragoza, y han sido incorporadas a los fondos de E:Zac. Todavía no se les ha proporcionado una signatura definitiva. Existe una investigación en curso sobre el uso de la vihuela de arco en la música española del siglo XVII a cargo de Pedro Reula Baquero.

31. J. López-CALO, Historia de la música española, cit., p. 214.

32. Ésta última fue publicada por C. Villanueva, Las lamentaciones de Semana Santa de fray José de Vaquedano, Santiago de Compostela, Universidad de Santiago, 1990. 
del repertorio (pérdidas ocasionales, desastres, descuido) o también como síntoma de que, en dichas fechas tempranas, los instrumentos de arco, como los de viento, no hacían sino sumarse a la práctica a cappella (o colla parte), duplicando o substituyendo voces, pero sin partes propias e independientes.

Al menos en el caso de las catedrales zaragozanas, y me atrevo a pensar que esto sucede en el común de las iglesias, los instrumentos actúan generalmente a razón de uno por parte, lo mismo que las voces; a este respecto, salvo para el caso de ciertas capillas muy numerosas las Capillas Reales, de las que existen abundantes testimonios ( $\sin$ necesidad de salir del archivo base de nuestra investigación, en él se conservan algunas composiciones de Juan Pérez Roldán destinadas a la Real Capilla de la Encarnación, donde ejerció antes de ocupar el magisterio en El Pilar; por los nombres de los cantores anotados en sus particellas se aprecia la presencia de dos y hasta tres cantores por parte en cualquiera de los $\operatorname{coros}^{33}$ ) - , debe ponerse en tela de juicio la muy extendida afirmación de que en las obras policorales el primer coro era de solistas mientras el segundo era normalmente más numeroso, cantado por el grueso de la capilla. Ciertamente, en la segunda mitad del XVII existía la posibilidad, denostada por los teóricos, de duplicar voces, más concretamente, de que un coro completo fuese doblado por otro (llamado «coro duplicado» o «coro de capilla», o «ripieno», citado por Valls ${ }^{34}$ como costumbre italiana adoptada recientemente en España por los «compositores de poca monta», pero ya presente en obras de Juan Pérez Roldán o Joseph Ruiz Samaniego), en obras falsamente a 12 (a 8 con un coro duplicado). Pero tanto la documentación conocida, que demuestra que las capillas muy numerosas eran una rareza en el siglo XVII, como las propias fuentes musicales, que muchas veces traen los nombres de los intérpretes a los que se destinaba la composición, y los tratados de música práctica, parecen confirmar que, en cualquier caso, a mayor número de intérpretes se prefería una composición a mayor número de partes: si hay ocho cantores se compone a ocho, si doce, a doce, si dieciséis, a dieciséis, siempre que la habilidad y el oficio del maestro lo permitan. Además, aparte de las posibilidades de cada capilla, el número de cantores y ministriles que intervenían estaba perfectamente regulado por el calendario litúrgico y dotado de una provisión económica, de modo que, entre los días de canto de órgano, había fiestas de a cuatro, de a ocho, etc. Hay numerosos testimonios de estas circunstancias, y bastará citar uno, referido al organista Andrés de Sola, que, siendo maestro de capilla ocasional en La Seo de Zaragoza en 1688, hizo intervenir en una fiesta de a ocho al arpista, cuando «nunca han ido sino 2 tenores, 2 tiples, 2 bajos y 2 contraltos» con el órgano, lo que motivó la protesta de los cantores, puesto que, al intervenir uno más, todos cobraban menos ${ }^{35}$. Por lo que respecta a los coros duplicados, en un archivo tan amplio como $E$ : Zac (ca. 1500 composiciones del siglo XVII), en muy pocas fuentes encontramos alusiones a dicha práctica: tres de ellas son villancicos de Juan Pérez Roldán, tal vez todos ellos procedentes de su etapa madrileña en la Encarnación (B-3/32, a 12, con

33. Ejemplos en $E: Z a c$ B-3/31 y B-10/203.

34. F. VALLS, cit., ff 145-145v.

35. Actas Capitulares, 1688,30 de octubre. 
dos juegos de particellas para el coro III, donde dice «Duplicado»; B-9/177, a 8 - de 1658, es decir, de la Encarnación-, con tres juegos de particellas para el coro II, en los que dice «D», que puede interpretarse como «Duplicado»; B-10/202, a 8, con el coro II duplicado); la cuarta pertenece a Joseph Ruiz Samaniego (B-46/686, a 12 - en realidad a 8-; el coro II tiene otro juego de particellas que figura como coro III, donde se indica «Duplicado»). También en el ámbito de la catedral de Barcelona encontramos una alusión al coro duplicado, en una ocasión muy especial, cuando se reúnen varias capillas de música, dirigidas por Marcián Albareda, ante el virrey, Conde de Santa Coloma, en un oficio «a cant d'orga a vuit cors, la composició era a quatre duplicats» ${ }^{36}$. Es decir, parece que la práctica del coro duplicado era un recurso ocasional, extraordinario, y no la norma, ni siquiera la costumbre.

Volviendo a los instrumentos, en el caso de los de arco tal vez pudieran duplicarse (desde luego, en el ámbito de la corte era posible, dado que el número de violinistas lo permitía ${ }^{37}$ ). La duplicación parece mucho más rara en los instrumentos de viento. Sin embargo, existen casos particulares de lo que podemos suponer cierta especulación tímbrica, como el de algunas composiciones de Joseph Ruiz Samaniego: varias piezas conservadas en E: Zac atribuidas a este maestro presentan partes instrumentales duplicadas, como demuestra el hecho de que en la misma particella vengan anotados los nombres de dos ministriles (vg.: Adrián y Fabro, o Campo y Alcalá); curiosamente, en una de estas obras figura una parte vocal destinada a dos cantores, y en otra el Coro II es doblado por el Coro III (en cuyos papeles se indica duplicado), lo que, en el fondo del siglo XVII de E: Zac son notables excepciones; así, encontramos una parte de tiple sonada por Adrián López (documentado como bajonista y sacabuche) y Francisco Fabro (tañedor de corneta y chirimía), o una parte de bajo sonada a la vez por dos ministriles (mosén Francisco Alcalá —bajón o sacabuche - y Miguel Campo —bajón o chirimía-), en E: Zac B-47/698 (Navidad). Adrián y Fabro tocan juntos también en B-20/363 (Reyes, 1663), B-20/367 (Reyes), B-45/676 (Reyes), B-46/686 (Reyes y Resurrección) y B-46/690 (Navidad y Reyes 1663). Esto se da en seis villancicos de Navidad y Reyes, dos de los cuales están fechados en 1663. Cabe la posibilidad de que ambos ministriles tocaran instrumentos iguales (¿dos bajoncillos juntos?), aunque por la documentación existente me inclino a pensar que sus instrumentos eran distintos (Adrián López nunca figura como corneta o chirimía, ni Fabro como bajoncillo o sacabuche, aunque estos datos no necesariamernte han de ser excluyentes). De ser instrumentos diferentes, esta suma de timbres (tal vez corneta más bajoncillo, cuyos timbres pueden fundirse satisfactoriamente) pudiera parecer influenciada por una mentalidad organística (suma de registros: uno de lengua más uno labial), o tal vez se tratara de un uso tradicional, hasta ahora no conocido, que pudo influir en la conformación de algunos registros de los órganos, o en costumbres de registración. En cualquier caso, fueran iguales o diferentes los instrumentos, todavía pueden formularse muchas preguntas: ¿tocaban siempre juntos o se turnaban? (las partes examinadas no parecen tan fatigosas como

36. Cfr. J. PAvia i Simó, La música a la catedral de Barcelona durant el segle XvII, Barcelona, Fundació Salvador Vives Casajuana, 1986, 207-208.

37. Véanse los de J. Subirá, B. Lolo y L. Robledo sobre la vida musical en la corte, citados en la bibliografía. 
para obligar a dos instrumentistas a turnarse ${ }^{38}$, pero ¿podrían alternarse dos instrumentos distintos en función del texto o del carácter de la música?); en caso de tocar juntos, ¿lo hacían en la misma tesitura o en octavas?; ¿podían acaso tocar a veces juntos y a veces por separado, produciendo un efecto de F y $\mathrm{P}$, o de tutti y solo, lejanamente vinculado a lo que se practicaba en ese tiempo en Italia como incipiente concerto grosso? Sabemos del uso de estas técnicas en Roma desde los años 40 en el ámbito teatral (obras de Luigi Rossi), y algo más tarde en piezas instrumentales (sinfonías) destinadas a preceder grandes composiciones vocales religiosas (Strade1la $)^{39}$; además, en España en esta época ya existía, como se ha visto, el uso del «coro duplicado» o «coro de capilla». El tema es interesantísimo de cara a la interpretación y a la comprensión de esta música, y cabe desear que nuevos testimonios arrojen algo de luz sobre los interrogantes propuestos.

Con frecuencia se alude a una supuesta indefinición tímbrica de las partes instrumentales, y al carácter marcadamente vocal de las mismas. Desde luego, la escritura instrumental no suele presentar características idiomáticas propias del violín, del bajoncillo o de la corneta. Incluso para fecha más avanzada, resulta significativa la conocida frase de Valls, referida a los instrumentos de moda en su tiempo: «El estilo de Música entre violines, oboesses, y flautas casi es el mismo, pues lo que executa el violín, lo practica el oboé, y la flauta...» ${ }^{40}$ (la cursiva es mía). Del mismo modo, las partes instrumentales, incluso en obras exclusivamente instrumentales, son escasamente o nada virtuosísticas, a pesar de que, según los teóricos, lo que diferencia la composición para instrumentos de la vocal es que aquéllos pueden hacer más glosa. Una excepción, no virtuosística pero sí al menos dotada de una escritura más glosada, puede ser la obra de bajo [bajón] conservada en $E$ : Zac, B-41-638, antes citada. Todo esto hace pensar que la glosa quedaba regularmente reservada al terreno de la improvisación. De cualquier modo, en gran parte de las fuentes se especifica verbalmente la clase de instrumento a la que se destinan las obras, y, si es difícil encontrar figuraciones o giros propios de cada instrumento o familia, no lo es tanto descubrir determinadas asociaciones tímbricas y conceptuales, dadas por las características sonoras de los diferentes instrumentos. En primer lugar, muchas veces la escritura instrumental está sometida a condicionamientos técnicos de los propios instrumentos o a costumbres más o menos arraigadas. Citaré dos ejemplos de diversa índole: el hecho de que las partes de violín rara vez desciendan por debajo del Re3 no ha de deberse necesariamente a que de ese modo sus partes sean intercambiables (ejecutables por instrumentos de viento tiples), sino a que la cuarta cuerda del violín, de tripa como las demás, no comenzó a fabricarse entorchada hasta finales del siglo XVII, lo que, siendo

38. Sobre lo fatigoso de tañer los instrumentistas de viento, cfr. S. DE Covarrubias y Orozco, Tesoro de la Lengua Castellana, o Española, Madrid, 1611 (reed. México, Turner, 1984), 436, en relación con las chirimías: «...es menester para tañer la chirimía manos y lengua y aun traer bragas justas por el peligro de quebrarse...». También, aunque refiriéndose a instrumentos más modernos (el clarín y la trompa), cfr. F. VALls, cit., f. 144 v.: «...vaya el compositor con cuydado que no hayan de tocar muchos compases consecutivos, porque sería rebentarles, y assí que no passe de dos, o tres para que puedan descansar». $168-180$

39. Cfr. O. JANDER, "Concerto Grosso Instrumentation in Rome in the 1660's and 1670's", JAMS, XXI, 2, 1968-,

40. VAlls, cit., f. 144 r. 
gruesa, corta y sometida a una tensión relativamente baja, dificultaba en gran medida que se mantuviese afinada ${ }^{41}$. El segundo ejemplo es el de la copla de chirimías, cuyas partes ordinariamente, al menos en determinados lugares, se escribían, según explica Nassarre y corroboran multitud de ejemplos conservados en $E$ : Zac, un tono bajo, por considerarse las chirimías, junto al sacabuche, instrumentos transpositores ${ }^{42}$. Por otra parte, con frecuencia los instrumentos o agrupaciones instrumentales se asocian a determinadas situaciones marcadas por el texto o la funcionalidad de la composición: obras policorales de gran solemnidad, de matiz áulico, donde a veces se remedan aires marciales o heráldicos, con imitación de toques de clarín (instrumento que raramente interviene en la realidad hasta finales del siglo, pero que con frecuecia es imitado durante toda la centuria), suelen contar con un coro de chirimías con su bajo «natural», el sacabuche. Las chirimías, tocadas a la manera del siglo XVII (con caña ancha que se introduce por completo en la boca, formando una suerte de cápsula de aire al oprimir los labios contra la pieza comúnmente llamada pirouette $^{43}$ ), producen un sonido áspero y de gran volumen, apto para fundirse con las voces en una gran composición policoral de carácter relativamente pausado, pero no tanto para el acompañamiento de una voz sola. Sirven para este cometido los bajoncillos, mucho más flexibles en su manejo y, como las cornetas, de mayor agilidad, lo que permite su uso en obras o pasajes de mayor ligereza, acompañando a voces solas, etc. Los instrumentos de arco exceden a los vistos en extensión y en posibilidades dinámicas, como reconoce Nassarre: «... el sonido es más y menos, según la voluntad del Músico;... circunstancia en que el oído halla mayor deleyte,... Por esso semejantes Instrumentos [los de cuerdas de tripa en general] son más al caso para acompañados con las vozes naturales...» ${ }^{44}$, y, por alguna razón que desconozco, siendo los instrumentos propios del teatro, de los bailes y de la diversión cortesana, se consideran también indicados para el acompañamiento de la música fúnebre y de Semana Santa. Valls, a este respecto, va más allá proponiendo para músicas fúnebres el acompañamiento de una voz sola con dos violines, sin bajo ${ }^{45}$; pero opino que sigue perteneciendo a esta misma tradición. Como puso de manifiesto L. Robledo ${ }^{46}$, en la corte de los Austrias fue común el uso de instrumentos de arco para acompañar la voces en las ceremonias de Semana Santa desde comienzos del siglo XVII (el testimonio más antiguo que aporta es de 1601). Se sabe que los conjuntos de vihuelas de arco participaban en fiestas determinadas: Navidad, Inocentes y, sobre todo, Cuaresma y Semana Santa, concretamente en Completas y en los Maitines (para acompañar las lamentaciones), y también en solemnidades fúnebres, como, por

41. D. Boyden, "Violin", en New Grove Dictionary of Music and Musicians (vol. 19, 828) cita numerosos testimonios sobre esta circunstancia. Cfr. también D. BoYDEn, The History of Violin Playing form its Origins to 1761, Oxford, Clarendon Press, 1990.

42. Cfr. mi artículo "Notas sobre la transposición en voces e instrumentos en la segunda mitad del siglo XVII: El repertorio de La Seo y El Pilar de Zaragoza", en Recerca musicologica, IX-X, 1989-90, 303-325. También la voz "Transposición" en Diccionario de la Música Española e Hispanoamericana, Madrid, ICCMU (en prensa).

43. Sobre el modo de tocar la chirimía, cfr. S. DE Covarrubias, cit., así como A. Baines, Woodwind Instruments and their History, Londres, Faber and Faber, 1967, y D. Munrow, Instruments of the Middle Ages and Renaissance, Londres, Oxford University Press, 1976.

44. NASSARRE, cit., I, p. 464.

45. VALLS, cit., f. 145v.

46. L. Robledo, "Vihuelas de arco y violones en la corte de Felipe III", Actas del Congreso Internacional "España en la Música de Occidente» (Salamanca, 1985), Madrid, I.N.A.E.M., 1987, vol. II, pp. 63-76. 
ejemplo, el 13-IX-1607, en el aniversario de la muerte de Felipe II. También, en fecha más tardía, tal vez durante su estancia en Madrid, como se ha dicho, José de Vaquedano compuso una lamentación con vigüelas. Los violines y violones, sin abandonar su tradicional repertorio de danza, fueron penetrando en la Capilla Real hasta que en 1630 eran ya nueve, desplazando progresivamente a las vihuelas de arco, precisamente en la músicas de Cuaresma y Semana Santa. Sorprende que los violines, tradicionalmente vinculados a los saraos y espectáculos teatrales, tuvieran cabida especial en una celebración litúrgica en que el uso del órgano, instrumento propio de la iglesia, estaba prohibido. Si la utilización de violines en la iglesia fue aceptada en el siglo XVII, en el XVIII, cuando se generalizó en la práctica, suscitaría no pocas críticas, como las de Feijoo, que serían contestadas, entre otros, por Joaquín Martínez de la Roca.

En relación con la posible adopción de este uso, tal vez en origen propio de la corte, en determinados lugares periféricos, hay dos casos que quisiera comentar brevemente. En primer lugar, la citada lamentación de Ruiz Samaniego, que inaugura una tradición en el ámbito zaragozano viva durante todo el siglo XVIII. La obra debe fecharse después de marzo de 1668, puesto que una parte de bajo se halla copiada en el reverso de una carta recibida por el bajonista de El Pilar Adrián López, datada el 11 de dicho mes; sin duda el bajo se copió posteriormente, tal vez para la Semana Santa de $1669^{47}$. En ese caso, el uso de violines en la obra, instrumentos que, como he dicho, no existían en la plantilla de El Pilar - tampoco hay pruebas de que los tocaran los ministriles cuyo instrumento principal era la chirimía o el bajón-, puede explicarse por la presencia de los músicos de Don Juan de Austria, ya residente en Zaragoza; además, hay constancia documental de que éste prestaba algunos de sus violones para fiestas en La Seo y El Pilar ${ }^{48}$. El segundo caso tiene que ver con un peculiar instrumento de acompañamiento: tal vez deba interpretarse como una reminiscencia o imitación de los instrumentos de cuerda el uso de la llamada lira cali (el Geigenwerk descrito por Prætorius) en las funciones de Semana Santa en las catedrales de Toledo y Valencia ${ }^{49}$.

El siguiente punto a tratar es cómo se utilizan los instrumentos en las piezas vocales, cómo se compone para ellos y cómo se espera que se comporten. En primer lugar, y en apoyo de las teorías sobre el carácter vocal de la música instrumental en la España del siglo XVII, cabe destacar que los tratadistas insisten en que la composición para instrumentos es igual que la composición vocal, se rige por las mismas reglas. Nassarre, sobre la composición de sinfonías, esto es, piezas instrumentales, dice que «se aya de ordenar en el mismo modo que el que dixe arriba acerca de las vozes naturales, assí en quanto al uso de las especies perfectas, como en quanto a las imitaciones, y en el modo de cargar sobre el acompañamiento...» ${ }^{50}$. De este modo, cualquier composición,

47. Cfr. A. Ezquerro y L. A. González Marín, "Catálogo del fondo documental del siglo XVII del Archivo Musical de las catedrales de Zaragoza (Zac)", en Anuario Musical, 46, 1991, 127-171.

48. Pueden encontrarse datos al respecto en los Libros de Común. Por otro lado, la contratación de músicos foráneos para determinadas fiestas era habitual en las catedrales zaragozanas, así como en otras iglesias principales de diferentes lugares.

49. Cfr. mis artículos "Lamentaciones" y "Lira cœli" en Diccionario de la Música Española e Hispanoamericana, Madrid, ICCMU (en prensa).

50. NASSARRE, cit., II, p. 306. 
siempre que se ajuste a las tesituras y extensiones convenientes, puede ser ejecutada por un conjunto instrumental: así se explica que Andrés Lorente proponga que sus ejemplos de composición, no concebidos específicamente como música instrumental, sirvan «para que en las Yglesias los ministriles las toquen por canciones en sus instrumentos, usando de la variedad de ellas en los ofertorios de las Misas y en otras ocasiones ${ }^{51}$. Sin embargo, existe un punto de divergencia entre la música vocal e instrumental: en la composición para instrumentos se admite más glosa que en la destinada a voces (Nassarre: «Y sólo se diferencian en que los passos pueden ser de más glos$s a$ en las de vozes artificiales, por razón de poderse executar mejor.» ${ }^{52}$ ), lo que raramente se aprecia en las fuentes musicales conservadas del siglo XVII. Estas generalidades valen tanto para las obras exclusivamente instrumentales como para las partes instrumentales de las obras vocales. Ya en este último supuesto, tanto Nassarre como Valls muestran una importante diferencia entre la música «antigua» (la del XVII) y la «moderna»: antiguamente los instrumentos formaban parte del entramado contrapuntístico, es decir, tenían partes propias y distintas de las vocales, y en sus relaciones debían observarse cuidadosamente las reglas del contrapunto; en cambio, modernamente se practica un tipo de composición más simple, en el que los instrumentos no se consideran voces y, por tanto, pueden duplicar ocasionalmente o de manera permanente a aquéllas en unísono, en octavas, etc., sin que ello produzca faltas, aunque provoque una disminución de la «armonía de la composición». Así lo expresa Nassarre: «Quando las obras son a quatro, a cinco coros, o a más, y uno u dos de ellos fueren de instrumentos, quando juntos todos, no lo errará el Compositor en que las vozes de los instrumentos canten en octavas de las vozes naturales: exceptando aquellos que cantaren la parte de el Baxo; que no será que canten lo mismo que las vozes particulares. Y assí sólo se ha de entender lo que digo de Violines, Chirimías, u otros semejantes. Y puede con alguna razón hazerse assí, porque, como ay variedad en la diferencia de la voz natural, a la de el instrumento, no es menos armonioso, aunque canten en octavas... En las composiciones de a ocho, a nueve y a diez, aunque sean con instrumentos, deven cantar todas las vozes con diferencia...» ${ }^{53}$. Y así lo explica Valls: «... a los principios, que se usaron [los instrumentos] unidos con las vozes, hazían su coro aparte, cuydando que entre ellos y las vozes no se dieran dos octavas, ni dos quintas, y todas las demás circunstancias no permitidas entre unas, y otras vozes; pero dexóse esta práctica, por la razón que estando atados a estas reglas, su estilo de cantar muchas vezes era violento, en passando la composición de ocho vozes.» ${ }^{54}$. Por otra parte, tanto Nassarre como Valls insisten en la discreción con que deben desenvolverse las partes instrumentales para no entorpecer la escucha de la voz y la comprensión del texto, por lo que es importante que, frente a la práctica moderna introducida a imitación de los extranjeros, en composiciones a pocas voces los instrumentos (como explicaba Nassarre también en lo relativo a la realización del continuo ${ }^{55}$ ) no doblen

51. A. Lorente, El porqué de la música, Alcalá de Henares, Nicolás de Xamares, 1672, p. 618.

52. NASSARRE, cit., II, p. 306.

53. Ibid., II, 332-333.

54. VAlls, cit., f. $145 \mathrm{v}$.

55. Remito de nuevo a mi artículo "El órgano y el acompañamiento en la música española del Barroco", en Rolde. $58-59,1991,45-52$. 
a las voces, sino que llenen las consonancias necesarias homofónicamente o bien callen mientras canta la voz y respondan en ecos o la anticipen a modo de pequeñas introducciones. Valls se refiere a este asunto en varias ocasiones: «Esto es contra el estilo introducido de algunos años, a esta parte, tocando el violín, o oboe lo mismo, que canta la voz, que sólo sirve de embarazarla, y no añadirle armonía.» ${ }^{56}$; «Quando a la Música se le añaden violines, es práctica común (siendo pocas las vozes) que cantando vozes, y instrumentos vayan unisonando con ellos; quando son quatro, y los violines dos van unidos con los tiples, o como le parece al compositor. Los Italianos, en algunas obras, acostumbran a los dos violines, añadirles una violetta que es un contralto; pero en bulla de instrumentos, casi no se oye: Quando los violines tocan solos, se procura un modo de cantar agradable, y dulce, y que lo más que pueda vaya cerca el un violín del otro. Con ellos se acostumbran hazer las aperturas, o introducciones de la obra, que se ha de cantar: éstas no han de ser muy largas, y si son para Música ecclesiástica, es muy del caso avisen de la intención, con que han de entrar las vozes; quando no, que aquel intento, o méthodo de cantar, con que empezaron le vayan prosiguiendo, y ajustándole con las vozes naturales; si éstas son pocas, no junte los instrumentos con ellas, hasta que todas hayan entrado, y se oyga enteramente todo el intento; y a lo último podrá unir instrumentos, y vozes pues entonces ya se ha repetido aquella letra, y se acaba aquel período, a satisfacción del Auditorio. / Lo mismo, que se ha dicho de los violines se debe entender de los oboesses. / Esto es lo que puede observar en un Lleno de Música de $4^{\circ}$, o más vozes; pero quando cante una sola voz, si le parece acompañarla con el violín, oboe, o flauta, imitándose, o remedándose voz e instrumento, o bien cantando juntos [pero no al unísono], que midiendo el instrumentista el instrumento con la voz que canta sale bien, y es muy grato al oído.» ${ }^{57}$. Acerca de las introducciones, Valls hace hincapié en la necesidad de que sean breves y se sirvan de los mismos motivos musicales que desarrollarán las voces: «En qualquier composición Ecclesiástica, o profana, hágase cargo el compositor, que lo principal de ella son las vozes, y que los instrumentos no son más, que un adorno, que se le añade; y en este supuesto no aconsejo se siga la moda presente, que es empezar los instrumentos, con una introducción, o apertura muy larga, y las más vezes impertinente, y separada de la obra que se ha de cantar.» ${ }^{58}$.

Todas estas normas y reflexiones de Nassarre y Valls se encuentran aplicadas en numerosas composiciones desde los años 30 del siglo XVII. En otros lugares ${ }^{59}$ aludí a los posibles estilos de acompañamiento de obras vocales con varios instrumentos practicados a lo largo del siglo: un estilo homofónico (melismático según Kircher-Valls), un estilo contrapuntístico-imitativo y un estilo de respuestas o ecos, a los que hay que sumar otra modalidad, descrita imprecisamente por Valls al referirse a composiciones vocales en imitación o cánones («...si en ella quisiere el compositor añadir algunas de las habilidades en las vozes, de fugas, cánones, \&c. y si le parece ajus-

56. VALLS, cit., f. 106r.

57. Ibid., ff. $145 \mathrm{r}-145 \mathrm{v}$.

58. Ibid., f. 146r.

59. Cfr. L. A. GonzÁlez MARín, "El teatro musical español del siglo XVII y sus posibilidades de restauración”, en Anuario Musical, 48, 1993, 63-101, y F. Coppola-M. García Bustamante: "El robo de Proserpina" (1678), Barcelona, Consejo Superior de Investigaciones Científicas, 1996 
tar los instrumentos, haga, que sólo toquen algunos golpes, para que se oyga el primor sin confusión.» ${ }^{60}$ ), consistente en acordes aislados, frecuentemente al dar del compás pero también posibles a contratiempo, resaltando o contrarrestando los acentos del texto. Estos modos de unir los instrumentos a las voces pueden apreciarse en los Ejemplos 1, 2, 3 y 4, así como en algunas ediciones existentes ${ }^{61}$. Existen, como he dicho, algunos testimonios de duplicación de partes vocales con instrumentos (por ejemplo, obras de Joseph Ruiz Samaniego), y, entre ellos, destaca una copia de un Magníficat a 8 de Aguilera de Heredia (de la edición zaragozana de 1618), fechable por su escritura en la segunda mitad del siglo XVII ${ }^{62}$, en la que los dos tiples y el alto del coro I están doblados por violines (el violín que dobla al alto, a la octava aguda: es una práctica que, por establecer un paralelismo en la música europea, se da frecuentemente en madrigales de los libros $7^{\circ}$ y $8^{\circ}$ de Monteverdi). Es decir, lo que Nassarre y Valls consideraban una práctica recientemente introducida (tal vez haya que entender recientemente difundida o extendida), a veces despreciable por su escaso interés, existía, según parece, con anterioridad y no necesariamente por influencia italiana.

En cuanto a las composiciones exclusivamente instrumentales ejecutadas en las iglesias, todas ellas parecen tener, en origen, un vínculo con la música vocal, con la liturgia, esto es, se componen y se interpretan para introducir o enmarcar obras vocales de vastas proporciones (pasacalles, madrigales, o sinfonías o aperturas ), o para substituir fragmentos de obras vocales (versos en salmos, por ejemplo). Existen también las denominadas canciones (Lorente), cuya ubicación dentro del marco litúrgico no podemos precisar más que lo que el propio Lorente indica. Algunas de estas piezas son exclusivas de la música litúrgica latina (los versos), otras lo son de la música paralitúrgica en lengua vernácula (los pasacalles) y otras se usan en ambos géneros (los madrigales). Por lo que se refiere a los versos para ministriles, sólo conozco un ejemplo, aparte del citado de Quito, conservado en $E$ : Zac (B-91/1382), una breve composición a cuatro sobre cantus firmus datable en la época de Ruiz Samaniego ${ }^{63}$.

Los pasacalles, de los que podemos examinar algunos ejemplos (Ejemplos 5, 6 y 7), se hallan descritos en numerosas fuentes de los siglos XVII y XVIII (desde el método de guitarra de Briceño, pasando por Gaspar Sanz, hasta Valls), como fórmulas de introducción a las obras vocales en vulgar, tanto en la iglesia como en el teatro o en la cámara, destinadas a dar el tono a los cantores y a presentar el aire de la composición; siguen casi a rajatabla el esquema I-IV-V-I y pueden constituir introducciones más o menos largas según el número de diferencias que se

60. VALLS, cit., f. 160v.

61. Como ejemplos, cfr. algunas obras en J. Climent, Juan Bautista Comes. 1582?-1643. Obras en lengua romance II, Valencia, Institución Alfonso el Magnánimo, 1978 (el villancico Revolved esos archivos); F. BonASTRE, Nunc dimittis, a ll. Anònim, s. XVII, Quaderns de música històrica catalana, 4, Barcelona, Institut Josep Ricart i Matas, 1983; -: Francesc Soler-Obres Completes. Vol. III, I. Completes a 15 (1686), Barcelona, Biblioteca de Catalunya, 1988; L. A. GonZÁLEZ Marín, Seis villancicos del Maestro de Capilla de El Pilar Don Joseph Ruiz Samaniego (1661-1670), Zaragoza, Institución Fernando el Católico, 1987 (los villancicos Sirenas del viento y De esplendor se doran los aires).

62. Citada por Querol en su catálogo de dicho archivo ("El archivo de música de la colegial de Jerez de la Frontera", AnM, 30, 1975, 167-180) como de comienzos del XVII.

63. Publicado en L. A. GonZÁLEZ MARíN, "Dos nuevas piezas españolas del siglo XVII para conjunto instrumental", en Nassarre, IX, 2, 1993, 161-170. 
improvisen (para ello existen numerosos repertorios en libros para guitarra, instrumento acompañante preferido en la práctica musical casera). Los pasacalles muestran un evidente parentesco con los bajos estereotipados que desde el siglo XVI se utilizan para la construcción de diferencias (el Ruggero, la Romanesca, la Chacona, etc.), y existe una abundante y documentada bibliografía sobre el tema (Walker, Hudson). No se trata propiamente de composiciones de música, sino del desarrollo más o menos imaginativo de una fórmula, y da la impresión de que, al margen de los ejemplos para ministriles que se nos han conservado, debía de ser una práctica habitual introducir con pasacalles, sonados por los ministriles o improvisados por los acompañantes (órgano, arpa, etc.), todas o casi todas las obras en vulgar, o al menos las coplas: esto parece justificado por la nota que aparece en las particellas de un villancico de Roldán (E: Zac B3/32), donde se dice «las coplas se repiten sin el pasacalle»; incluso Valls, en fecha tan tardía, da a entender que siempre se tocan pasacalles: «En toda la Música de idioma vulgar sirven los passacalles, que son como una introducción a lo que se ha de cantar. Estos consisten en quatro compasses de Música con dos cláusulas, la p.ra al Diatessaron del Tono, y la $2^{\text {a }}$ al Diapasón.» ${ }^{64}$

No me extenderé sobre los madrigales, de los que he tratado en varias publicaciones. Baste con recordar que el uso del término madrigal con el significado de composición para instrumentos aparece en el ámbito musical zaragozano del siglo XVII. Propiamente alude a las piezas ejecutadas por los ministriles antes y después de determinadas ceremonias con importante participación musical o de ciertas composiciones de considerable extensión (por ejemplo, el canto del Símbolo de San Atanasio que Urbán de Vargas puso en música por encargo de un racionero de La Seo de Zaragoza, Juan de Arruego, a mitad de siglo — E: Zac LS-19_65, o algunos villancicos de Reyes). En cualquier caso, las dos obras que con ese apelativo se conservan en E:Zac ilustran sobre dos tipos de composición diferentes, en cuanto a número de movimientos, textura, etc.

Tal vez deberían denominarse madrigales (de hecho, en el ámbito aragonés a buen seguro hubieran recibido tal nombre) los ritornellos que se incluyen en las Completas de Francesc Soler ${ }^{66}$, muy semejantes por su instrumentación y por diferentes parámetros de la composición - el uso de células rítmicas típicas de la proporcioncilla, la actuación de los instrumentos en breves solos imitados, agrupados por afinidad tímbrica en bloques que se responden en ecos- al madrigal negro que hemos mencionado.

Los madrigales conservados, así como el testimonio literario del racionero de Zaragoza Juan de Arruego, son testimonio de que en la segunda mitad del XVII ya existía la práctica de ejecutar composiciones instrumentales relativamente extensas precediendo a algunas obras vocales, piezas «exentas», separadas de la obra que precedían o enmarcaban, a diferencia de los pasacalles, que, aparentemente, eran sucedidos por la pieza que introducían sin solución de continuidad.

64. VALLS, cit., f. 176v.

65. Esta obra ha sido editada por A. EzQuerro en La música vocal en Aragón en el segundo tercio del siglo XVII, Tesis Doctoral, Barcelona, Universidad Autónoma, 1997.

66. Cfr. la edición de F. Bonastre, Francesc Soler-Obres Completes. Vol. III, 1. Completes a 15 (1686), Barcelona, Biblioteca de Catalunya, 1988. 
Los madrigales son, pues, independientes (aunque en el caso del citado de Roldán, tiene una clara relación temática con el villancico sucesivo, del que anticipa los dos motivos principales, del estribillo y de las coplas), circunstancia que Valls, en 1742, consideraba una novedad reprobable: «... no aconsejo se siga la moda presente, que es empezar los instrumentos, con una introducción, o apertura muy larga, y las más vezes impertinente, y separada de la obra que se ha de can-

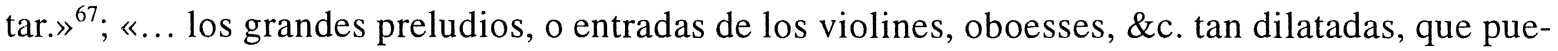
den servir para una larga symphonía, o concierto de los que sirven de intermedios para descanso de las vozes; estos preludios las más vezes no tienen ninguna connexión con lo que se ha de cantar, añadiéndose a esto que empezando a cantar las voces (que será al cabo de 200 compases)... El remedio de esto es: que los preludios de la obra no sean tan largos, y si se puede avisen de lo que se ha de cantar...» ${ }^{68}$.

Hay, naturalmente, en el siglo XVII introducciones instrumentales de obras vocales que coinciden con la recomendación de Valls; su presencia es mucho más abundante que la de madrigales o composiciones similares aisladas. Generalmente carecen de denominación propia en las fuentes musicales, pero podemos aplicarles las que los teóricos usaban de manera indistinta (Nassarre: «... se llaman Simphonías todas aquellas composiciones que constan de vozes artificiales, sean flatulentas, o de cuerda, y de éstas se componen, a dos, a tres, y a quatro vozes.» ${ }^{69}$; Valls: «Entran también en este estylo [el phantástico] las symphonías, sonatas, y Tocatas, que dezía (que en el tiempo presente casi son una misma cosa con diferentes nombres) de qualesquiera instrumentos. La symphonía es un concierto de tres, quatro, o más instrumentos como violines, oboesses, clarines, y flautas. Las Tocatas y Sonatas son por ordinario, de una voz sola, con el acompañamiento.» ${ }^{70}$; he encontrado el término tocata en una fuente de 1665 , que luego veremos; los demás sólo aparecen en fuentes más tardías). Esas introducciones a las que siguen las partes cantadas sin solución de continuidad se dan en obras en vulgar — villancicos- No las he encontrado, en los repertorios del siglo XVII, en obras en latín. En éstas se da el caso de que, en ocasiones, los instrumentos entran uno o dos compases antes que la voz o voces, en imitación o simplemente para dar el tono, cumpliendo una función similar a la de los pasacalles (pueden verse ejemplos en la lamentación Jod. Manum suam, «con vigüelas» de Vaquedano ${ }^{71}$, o en la citada lamentación con violines de Joseph Ruiz Samaniego). Tal vez se deba a una consideración de que el texto, en las obras litúrgicas, es demasiado importante como para hacerlo preceder de las evoluciones de los instrumentos; o tal vez en las obras litúrgicas fuera más frecuente de lo que pensamos el uso de madrigales exentos, cuya composición quizá no necesariamente tendría que ser responsabilidad del autor de la obra vocal. Volviendo a las composiciones paralitúrgicas, existen numerosos ejemplos de introducciones breves unidas a la pieza vocal (véase el Ejemplo 8, de Urbán de Vargas, en el que la introducción imitativa de 7 compases enlaza con un pasacalle

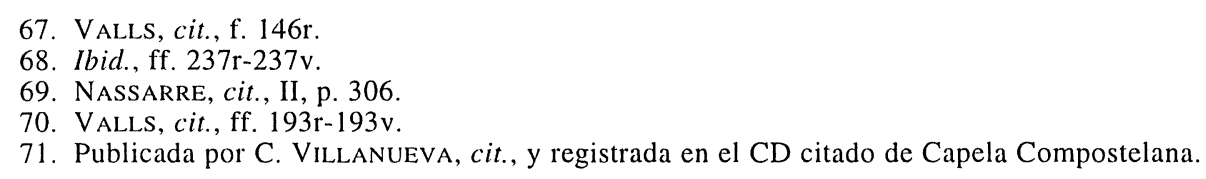


ALGUNAS CONSIDERACIONES SOBRE LA MÚSICA PARA CONJUNTOS INSTRUMENTALES DEL SIGLO XVII ESPAÑOL

- cc.8 al 11- antes de comenzar las partes vocales; son muy interesantes asimismo las introducciones de dos villancicos a la Virgen del Pilar de Joseph Ruiz Samaniego, titulados Sirenas del viento y De esplendor se doran los aires ${ }^{72}$ ). En ocasiones se anticipa en estas introducciones el material temático que elaborarán las voces, e incluso se da el caso de que las voces repitan al pie de la letra lo que han sonado los instrumentos. Un ejemplo particularmente interesante se encuentra en otra obra de Joseph Ruiz Samaniego — un villancico de Reyes, fechado en 1665 — $^{73}$, donde las coplas son precedidas por una Tocata de chirimías: ésta (Ejemplo 9) tiene como peculiaridad una escritura claramente idiomática en el tiple, pero no propia de la chirimía, a la que se destina, sino del clarín, instrumento que se imita. En efecto, al margen del estilo de llamada -notas repetidas...-, la parte del tiple sería perfectamente ejecutable en un clarín, pues todas sus notas se encuentran en la serie de armónicos de los instrumentos de metal. La imitación del clarín viene refrendada por el texto de la responsión: «...Rompan los aires / trompetas y clarines...». Pero es igualmente interesante el hecho de que las coplas sucesivas, a solo, repiten la parte del clarín fingido, por lo que asistimos a un caso de lo que Georgiades ${ }^{74}$ considera instrumentalización de la música vocal, fenómeno que en cualquier caso representa un estadio posterior a la asunción de una conciencia claramente instrumental, que supera la imitación de la vocalidad por parte de los instrumentos, hecho éste último que, de todos modos, sigue considerándose un ideal expresivo durante mucho tiempo, como demuestran las reiteradas alusiones a la voz humana como ejemplo a seguir en la búsqueda de una ejecución instrumental cantabile.

Sobre las recercadas conocidas (la de Jaca, las de la Biblioteca de Cataluña y la obra de bajo conservada en $E$ : Zac, que me atrevo a incluir en este apartado por su parentesco con las demás), puede decirse que recuerdan vagamente a las canzone italianas, aunque con una idea del desarollo temático muy inferior, que suele limitarse a las progresiones o secuencias, a la repetición de breves esquemas melódico-rítmicos a lo largo del círculo músico, que diría Valls. Se asemejan, en fin, a los tiples y bajos solos de los tientos de medio registro, tan abundantes en el siglo XVII desde su introducción por Aguilera y Peraza, lo que las hace aparecer ante nuestros ojos como composiciones genuinamente españolas. Como nota curiosa, en la Resercada a dúo que publicó R. Escalas se incluye una especie de giga, sin duda, dada la fecha de la fuente (1692), por influencia de las sonatas italianas que ya llegaban, al parecer masivamente, y en especial las de un compositor que causó furor en toda Europa: Arcangelo Corelli.

Así, en varios repertorios manuscritos que podemos situar entre los últimos años del siglo XVII y la primera década del XVIII, encontramos un buen número de sonatas de Corelli, copiadas en su disposición original (para violín y bajo, o para dos violines, violón y continuo) o en adaptaciones más o menos pintorescas (para tecla, para arpa). Uno de estos repertorios (dejando aparte las fuentes conservadas en la Biblioteca de Cataluña y las adaptaciones de los mss. de Martín

72. Publicados y comentados en L. A. González Marín, Seis villancicos del Maestro de Capilla de El Pilar Don Joseph Ruiz. Samaniego (1661-1670), vol. IV de Polifonía Aragonesa, Zaragoza, Institución Fernando el Católico, 1987.

73. Se trata del villancico de Reyes Ya rie el alba, de 1665 (E:Zac B-46/693).

74. Tl Georgiades, Musica e linguaggio, Nápoles, Guida Editori, 1989 (1ª ed. 1974). 
y Coll) pertenece a un fondo eclesiástico, en cuyo ámbito debió de utilizarse: me refiero al arriba citado manuscrito de la catedral de Jaca. Bien conocido y utilizado por quienes investigan la música organística, el manuscrito de Jaca contiene numerosas composiciones de Cabanilles, junto a otras de Diego Jaraba y anónimas, todas ellas para órgano o tecla. Incluye también composiciones para clave, de autores no identificados y de procedencia probablemente francesa. Junto a esta colección, de otras manos y en cuadernillos diferentes, existen copias de 6 sonatas de Corelli (son las sonatas en trío: X, Op. 3; XI, Op. 1; XI, Op. 2; IX, Op. 2; XII, Op. 3; X, Op. 4 ; todas ellas publicadas en $1681,1685,1689$ y 1694), que reciben indistinatemente el título, en la fuente hispana, de Sonata y Sinfonía. Además hay otras 12 sonatas en trío que no he podido identificar (algunas se denominan sinfonías, sin que se aprecien diferencias de composición con las sonadas o sonatas), una sinfonía y una sonada a solo con acompañamiento, dos sinfonías a 3 violines y bajo, una pieza a 6 (4 instrumentos tiples, alto y bajo, posiblemente dos flautas u oboes, dos violines, violeta y bajo), y numerosas composiciones a 2 (tiple y bajo), que pudieran ser para tecla o, posiblemente, para violín y bajo. Tal vez algunas de las piezas anónimas pertenezcan a compositores hispanos, aunque su estilo es decididamente italiano. Entre ellas destaca una colección de 12 Balletti seguidos de sus correspondientes correntas, gigas, sarabandas o alemanas, colección muy similar en estilo a la de bayletes que publicó R. Escalas (de estos 6, los 3 primeros se componen del baylete propiamente dicho, seguido de un minuet, forma de origen francés que se introduce en las sonatas italianas, y también en las sinfonías italianas de óperas y oratorios, en los años 80 del siglo XVII). Sobre la fuente de Jaca, cabe destacar el hecho de que los cuadernillos que contienen música de órgano, diferentes de los que contienen la música para violines, a menudo están cosidos interrumpiendo algunas composiciones instrumentales, lo que puede interpretarse de diferentes maneras: es posible que todos los cuadernillos se cosieran juntos descuidadamente, en un momento muy posterior a la copia de todos ellos; pero también es posible que los cuadernillos organísticos se insertaran posteriormente en un volumen de música para conjunto, habiendo caído ésta en desuso por la razón que fuere. En cualquier caso, y sin entrar a especular sobre la posible utilización de estas composiciones en la iglesia (Valls, años más tarde, permitía el uso de sonatas de Corelli dentro del templo), hay que concluir que el manuscrito de Jaca necesita una investigación a fondo, una identificación de sus contenidos y un estudio sobre sus fechas de redacción, su posible procedencia, etc. ${ }^{75}$.

Para concluir el apartado de la música en las iglesias, hemos de volver a la cuestión inicial: ¿por qué encontramos tan escasas composiciones españolas para los ministriles? Indudablemente hay un problema de conservación, de interés o desinterés por determinados tipos de música. La música compuesta por los maestros de capilla se ha conservado porque así estaba establecido (era propiedad de la catedral y debía custodiarse en el archivo). En cambio, lo que tocaran los ministriles solos, cuyo status jurídico y social se encontraba en un nivel diferente al de los músicos (es decir, los cantores), organista y maestro de la capilla, no siempre era respon-

75. Espero poder ofrecer próximamente una descripción del contenido de música para conjunto instrumental. Actualmente trabajamos en la identificación de las obras anónimas. 
sabilidad del maestro. En ocasiones los Cabildos dan instrucciones sobre las características de la música que deben ejecutar, pero no existen evidencias de que se pida al maestro de capilla que componga música para los ministriles. Éstos debían de recurrir ordinariamente a repertorios existentes de mayor o menor difusión (en este sentido, hay cierta cantidad de noticias sobre adquisición de libros para ministriles en diversas iglesias, e incluso se conserva alguno de estos volúmenes ${ }^{76}$ ), tal vez a composiciones propias, y quizá también a una práctica que existía en otro ámbito, en los teatros, que consistía en improvisar en grupo. Hay que pensar que, de existir, las composiciones de los ministriles - como las obras de los organistas, arpistas, cantores, que no tenían obligación de cederlas a la catedral - no se recogerían en archivos de ningún tipo, sino que debieron de permanecer en manos de particulares (los propios usuarios) mientras fueran de utilidad, cayendo posteriormente en el olvido.

\section{La música civil}

Todo lo concerniente a las recercadas, sonatas italianas, etc., a las que me he referido, nos acerca al ámbito de la música civil, que ha sido escasamente estudiado con rigor; es más difícilmente abarcable, pues las noticias pueden encontrarse en fuentes de información muy variadas y dispersas - protocolos notariales, archivos históricos, archivos particulares, archivos eclesiásticos, relaciones de fiestas, referencias en obras literarias, etc.- En cualquier caso, contamos con numerosas noticias sobre la utilización de conjuntos instrumentales, sea en compañía de cantores o independientemente, pero las fuentes musicales hoy conocidas son escasísimas. Me limitaré, pues, a anotar unas pautas para una investigación posterior.

Para el caso de la Corte, las casas nobles y sus paralelos en instituciones civiles, debe tenerse en cuenta la música para agrupaciones de instrumentos de carácter "heráldico": clarines y atabales (de los reyes y miembros de la casa real, nobles, arzobispos, también municipios, diputaciones, etc.). Existe un importantísimo repertorio de música para clarines conservado en uno de los manuscritos de Martín y Coll: se trata de las 29 Canciones diversas a dos clarines, más otra De un clarín solo con acompañamiento, del Huerto ameno de varias flores de música (1708 E: Mn, M. 1359), que han sido publicadas por Antonio Baciero como música para órgano con lengüetería, cuando, en realidad, da la impresión de que se trata de piezas para auténticos clarines, puesto que utilizan exclusivamente las notas posibles dentro de la serie de armónicos naturales que produce el clarín; la obra a solo tiene las mismas características, pero está dotada de un acompañamiento. Es una música del todo diferente a las composiciones partidas para órgano con registro de clarín, que, aun imitando las llamadas bélicas, abarcan toda la extensión de los registros partidos, que excede naturalmente las posibilidades del instrumento de metal. Además, debe tenerse presente que, aunque Martín y Coll era organista, no sólo recopiló música para órgano, como demuestra la presencia en sus colecciones de una tocata de Coreli, Otras tocatas alegres para violín y órgano, o 29 minuetes al violín. A pesar de su indudable interés, no me detengo más

76. Me refiero a los manuscritos de Lerma citados en la nota 2 . 
en este repertorio para clarines porque sus propias características - las limitaciones de los instrumentos y las dadas por la propia finalidad de esta música- lo sitúan en una posición marginal dentro del mundo de la composición.

A menudo las instituciones civiles - concejos, diputaciones- mantenían conjuntos de ministriles semejantes a los existentes en las capillas musicales eclesiásticas. Hay numerosas noticias, que, para el caso de Zaragoza, por ejemplo, han sido publicadas por Pedro Calahorra ${ }^{77}$. Lamentablemente no conozco nada de sus repertorios hasta fechas más tardías. También abunda la información sobre la participación de instrumentistas en actos festivos ${ }^{78}$ : músicos de todo tipo, individualmente o agrupados, intervienen en festejos callejeros de contenido civil o religioso (procesiones del Corpus, fiestas reales, etc.). Se trata por lo común de músicos ambulantes, cuyo repertorio escapa a nuestro alcance. Asimismo disponemos de gran cantidad de alusiones a la participación instrumental en fiestas más o menos privadas (bailes, saraos), en las que, según los testimonios la formación habitual para estas diversiones es el conjunto de instrumentos de la familia del violín. No se conserva música, que se sepa, ni tampoco hay evidencias sobre los compositores de este género de música. A través de los libros de danza (Esquivel, etc.) y también por los manuales de guitarra, o por la colección de Martín y Coll, conocemos tipos de danzas practicadas en España, pero es imposible saber cómo ejecutaban ese repertorio los violines. Sin embargo, es muy valioso el testimonio de Francisco Valls que, refiriéndose al estilo Chorayco (tomado de la categorización de los estilos musicales de Kircher, que Valls sigue y adapta a la música española de su tiempo y a la inmediatamente precedente), afirma que antaño (por otras referencias similares deducimos que se refiere básicamente al siglo anterior, esto es, al XVII) la música de bailes se componía y ejecutaba a cuatro, a diferencia de la de su tiempo, frecuentemente a una sola parte con el acompañamiento; asimismo apunta Valls que frecuentemente los compositores de música de danza son los propios maestros de baile: «... es el que sirve para danzas, y bayles; su composición consiste en una Música adequada para saltos, y movimientos de los danzantes. Quien más bien la compone son los mismos Maestros de danzas, y bayles; por ordinario es la composición de una voz sola con el acompañamiento: en lo antiguo, y según la moda española era de quatro vozes, pero el tiempo lo ha mudado todo. Sirve también este estylo, para las marchas de la tropa...» ${ }^{79}$ En el terreno «camerístico», hay una considerable cantidad de noticias sobre diferentes agrupaciones, tanto de músicos profesionales asalariados como de aficionados (conjuntos de vihuelas de arco en la corte, grupos mixtos con violines, tecla, guitarras, etc), procedentes de testimonios literarios, en muchas ocasiones debidos a viajeros extranjeros ${ }^{80}$. Tenemos

77. P. Calahorra: La música en Zaragoza en los siglos XVI y XVII, Zaragoza, Institución Fernando el Católico,

78. Sobre la música en actos festivos, cfr. L. A. GonZÁlez MARín, "Fuentes y método para el estudio de la música de las fiestas en la Edad Moderna", en Metodología de la Investigación Científica sobre fuentes aragonesas, 8, Zaragoza, Universidad de Zaragoza, ICE, 1993, 201-214, así como "La música y las fiestas en la Edad Moderna”, en Fiestas públicas en Aragón en la Edad Moderna, Zaragoza, Diputación General de Aragón, 1995, 57-68.

79. VALLS, cit., ff. 193v-194r.

80. Véase una interesante recopilación y bibligrafía sobre los viajeros extranjeros en J. M. Díez BorQuE, La vida española en el Siglo de Oro según los extranjeros, Barcelona, Edicioned el Serbal, 1990. 
noticias concretas sobre algunos repertorios practicados, como el Royal Consort de William Lawes y las obras de Jenkins, conocidas por Don Juan de Austria, o las composiciones de Andrea Falconiero y Henry Butler destinadas al citado Austria o a la Real Cámara ${ }^{81}$. En este caso se trata siempre de música de autores extranjeros, algunos vinculados a España (Falconiero, Butler) y otros no (Lawes, Jenkins).

\section{El teatro.}

Si en el ámbito de la música de iglesia las composiciones instrumentales no son ciertamente abundantes, en el caso de la música teatral del siglo XVII el panorama es desolador. En otro lugar he abordado la problemática que plantean las fuentes de la música teatral española, sus lagunas y vacíos, especialmente en lo que se refiere a la presencia de partes instrumentales distintas de la línea del acompañamiento. Como sucede con las fuentes de la ópera italiana hasta, aproximadamente, mediados del siglo XVII, en España muy raras veces se conservan partes instrumentales, y aún menos piezas independientes (sinfonías...), puesto que todo este ropaje instrumental no formaba parte propiamente de la composición de la obra, sino más bien de su interpretación o ejecución ${ }^{82}$. Así pues, hemos de contentarnos casi exclusivamente con noticias indirectas (relaciones, listas de gastos), entre las que destacan las acotaciones de numerosos textos teatrales. En el ámbito cortesano, desde comienzos del siglo XVII se registran amplios y variados conjuntos instrumentales; baste como muestra la variedad de «instrumentos en diferentes coros» presentes en La gloria de Niquea, de Villamediana, 1622: «quatro coros... unos de guitarras, otros de flautas y baxoncillos, otro de tiorbas, y otro de violones y laúdes», más clarines y chirimías, a cargo de los músicos de la Capilla Real ${ }^{83}$. Este tipo de formaciones policorales, en que se explotaban efectos derivados de la diversa situación de los coros, se repiten, en el marco de la corte, durante toda la primera mitad del siglo.

Desde mediados de siglo parece que se va perfilando un tipo de orquesta más estandarizado y más austero, formado por un conjunto de continuo —o acompañamiento — bien nutrido más unos pocos instrumentos de la familia del violín, una idea de orquesta que, aparentemente, se asemeja mucho a las orquestas italianas de ópera durante el siglo XVII ${ }^{84}$. Se diferencia de éstas

81. Cfr. I. Woodfield: "El primer Conde de Sandwich, una interpretación de William Lawes en España y los orígenes del pardessus de viole", en Musica Antiqua, 6, 1987, 6-7. Sobre Butler, cfr. E. V. PHILlips, ed., The Collected Works of Henry Butler, Madison, A-R Editions, Inc. Sobre A. Falconiero, cfr. D. FABRIs, Andrea Falconieri Napoletano. Un liutista-compositore del Seicento, Roma, Edizioni Torre d'Orfeo, 1987; también A. FalConiero, Il primo libro di canzone, sinfonie, fantasie..., Nápoles, Pietro Paolini \& Gioseppe Ricci, 1650 (ed, facsimil, Florencia, SPES, 1980).

82. He tratado este asunto en mi artículo "El teatro musical español del siglo XVII...", cit., así como en mi edición de El robo de Proserpina, trabajos a los que remito para lo referente al uso de los instrumentos en la música teatral española del siglo XVII.

83. Conde de Villamediana, La gloria de Niquea (ed. facsímil al cuidado de Felipe B. Pedraza), Almagro, Festival de Almagro/Universidad de Castilla-La Mancha, 1992.

84. Cfr. L. Bianconi y T. Walker, "Production, Consumption and Political Function of 17-Century Opera" (synoptic version), IMS Report of the twelfth congress Berkeley 1977, Kassel-Basel-London, Bärenreiter, 1981, pp. 680-711, y "Production, Consumption and Political Function of Seventeenth-Century Opera", Early Music History 4. Studies in medieval an early modern music edited by Ian Fenlon, Cambridge University Press, 1984, pp. 209-296. 
en la presencia masiva de guitarras, y podemos suponer, a través de ejemplos relativamente cercanos, que tal vez también en la textura, que en Italia, por los testimonios conservados, es frecuentemente a 5 ó a 4, y en España, por lo que veremos más adelante, da la impresión de que normalmente era a 3, o al menos sólo se anotaban las dos partes de tiple más el bajo. La consolidación de este tipo de orquesta pudiera estar ligada a la italianización del teatro musical promovida por Calderón y sus colaboradores músicos — en particular Hidalgo-, y se difunde en la segunda mitad del siglo incluso en los teatros públicos, al menos para ciertas fiestas de relieve: es el caso del estreno de La Azucena de Etiopía en el teatro de La Olivera de Valencia, ante el virrey, en 1665 , que se iniciaba con «concertados violones» ${ }^{85}$. Un ejemplo del uso standard de los violines en el teatro de corte puede desprenderse de determinadas acotaciones de Andrómeda y Perseo, de Calderón: entre otras intervenciones instrumentales — del «coro de los instrumentos»-, se habla de una batalla, naturalmente no conservada, «que tocaban los violones» ${ }^{86}$. En otros lugares se ha aludido también al uso emblemático de los instrumentos en sus intervenciones incidentales, así como a la textura típicamente española sin partes intermedias en los conjuntos de violones (dos o tres tiples y bajo; de existir esas partes intermedias, como parecen sugerir algunos documentos, por costumbre o por negligencia no se anotaban, como sucede en otros repertorios ${ }^{87}$ ), a la dependencia de las sinfonías teatrales españolas — tardías- de modelos italianos, a la presencia de tipos de composición intercambiables entre la iglesia y el teatro (los pasacalles) y a la total similitud de su uso conocido en los ámbitos eclesiástico y teatral, cuando se trata de unirse con las voces ${ }^{88}$.

\section{Conclusiones}

A lo largo del siglo XVII, en España, existe una práctica instrumental documentada, aunque los restos monumentales no sean tan abundantes. La escasez de fuentes se agudiza en el terreno exclusivamente instrumental (madrigales, sinfonías, etc.) y en el ámbito teatral.

85. Cfr. F. de la Torre y Sevil, Luces de la Aurora, Valencia, Gerónimo Villagrasa, 1665, p. 468.

86. Cfr. P. Calderón de la Barca, Andrómeda y Perseo (edición crítica y facsímil, sobre el ms. de Harvard, al cuidado de Rafael Maestre), Almagro, Museo Nacional del Teatro, 1994. Actualmente preparo mi edición de la música de esta obra, así como su ejecución en concierto.

87. Sobre las partes intermedias, cfr. L. Robledo, "Los cánones enigmáticos de Juan del Vado", en Poesía, 9 , 1980, 91-104, donde se alude a dichas partes intermedias. La constumbre de anotar únicamente las partes extremas se hace evidente en algunas fuentes manuscritas de ópera italiana del XVII, así como en los famosos impresos franceses de Ballard, de las obras de Lully. Aunque algo tardío, el comentario de VALls (cit. f. 145r) es sintomático: «Los Italianos, en algunas obras, acostumbran a los dos violines, añadirles una violetta que es un contralto; pero en bulla de instrumentos, casi no se oye...». De hecho, durante todo el siglo XVIII, fuera de la corte (Nebra, Corselli, etc.) es común encontrar un tipo de orquestación a la europea - andando el siglo, preclásica y decididamente sinfónica- pero sin violas.

88. Véase la nota 82. Los más antiguos ejemplos de partes instrumentales junto a las voces, en teatro en el ámbito español, pertenecen a El robo de Proserpina (1678), encontrándose los siguientes fechados en Destinos vencen finezas de Juan de Navas, que dio a conocer J. J. CarReras, "“Conducir a Madrid estos moldes»: Producción, dramaturdia y recepción de la fiesta teatral Destinos vencen finezas (1698/1699)", Revista de Musicología , XVIII, 1-2, 1995, 113-143. 
Según parece desprenderse de las fuentes conocidas, la música instrumental en la iglesia y la música instrumental en el teatro se diferencian fundamentalmente por los instrumentos usados en uno y en otro - mayor presencia de instrumentos de viento en las iglesias y de violines en el teatro-, circunstancia que, en el ámbito eclesiástico, fue interpretada a menudo como una dialéctica entre lo sagrado y lo profano, lo digno y lo indecente o, en definitiva, lo tradicional y lo nuevo. Pero no hay ninguna razón para pensar que los tipos de composición en la iglesia y el teatro fuesen básicamente diferentes. Por una parte, raras veces existe un uso idiomático de los instrumentos; por otra, dado que el estilo de composición de los villancicos y tonos a solo es idéntico al de la música vocal teatral, y a falta de una música instrumental teatral española conservada, cabe pensar que sucedería lo mismo que en el caso de la música vocal. Es problemático el estudio de las composiciones puramente instrumentales para el teatro (sinfonías, etc.), pues sólo se conocen ejemplos muy tardíos (Durón, a partir de 1696) o extranjeros, aunque vinculados con la música española (Coppola, 1678). Sin embargo, en el caso de las composiciones a solo acompañadas de instrumentos (por ejemplo, 2 instrumentos y bajo), de las que el repertorio litúrgico y paralitúrgico español ha dejado numerosos ejemplos, éstas presentan características del todo similares a los tonos a solo o coplas a solo con acompañamiento orquestal que incluye Coppola en su ópera, y también se asemejan, con más de 30 años de anticipación, a las tonadas que incluye Durón en sus primeras obras teatrales.

Merece un estudio serio el impacto que pudo ocasionar en España la llegada y difusión de colecciones italianas de sonatas en trío (particularmente, las de Corelli). En algunos casos, su influencia sobre las sinfonías teatrales españolas a partir de fines del siglo XVII parece decisiva. Asimismo, y volviendo a fechas más tempranas, sería deseable proseguir una investigación sobre el uso de los pasacalles en España y su posible relación con su presencia en la ópera en Nápoles (por ejemplo, en el manuscrito napolitano de La coronatione di Poppea de Monteverdi), así como en el desarrollo de formas instrumentales con basso ostinato.

Finalmente, debe resaltarse que, por encima de cuanto se ha dicho sobre el escaso valor idiomático de las composiciones para instrumentos en la España del siglo XVII, sí existe una clara conciencia instrumental. Si la primera faceta, negativa, de esta conclusión se manifiesta en la ausencia de fuentes que demuestren la existencia de un desarrollo instrumental virtuosístico - no parece existir una escuela de violín como en diferentes puntos de Italia-, la segunda, positiva, se hace patente a través de algunos — pocos, pero valiosos- ejemplos de especulación tímbrica, de combinación de sonoridades contrapuestas o complementarias, y en el juego de imitación a que en ocasiones se someten voces e instrumentos, asumiendo aquéllas unas características puramente instrumentales, o copiando algunos de éstos los elementos más peculiares de otros instrumentos de diferente naturaleza. 


\section{Bibliografía selecta}

Algunas fuentes históricas:

BRICEÑO, L.: Método mui facilíssimo para aprender a tañer la guitarra, París, P. Ballard, 1626. Cerone, P.: El melopeo ó Maestro, Nápoles, 1613.

Covarrubias y Orozco, S. de: Tesoro de la Lengua Castellana, o Española, Madrid, 1611 (reed. México, Turner, 1984).

Diccionario de la lengua castellana (Diccionario de autoridades), Madrid, Francisco del Hierro, 1726, 1732, 1737.

Lorente, A.: El porqué de la música, Alcalá de Henares, Nicolás de Xamares, 1672.

NASSARre, P.: Escuela música según la práctica moderna, Zaragoza, Herederos de Diego de Larumbe, 1724 y Manuel Román, 1723 (ed. facsímil: Zaragoza, Institución Fernando el Católico, 1980).

Prætorius, M.: Syntagma musicum, Wolfenbüttel, 1619 (ed. facsímil: Kassel, Bärenreiter, 1958).

RABASSA, P.: Guía para los principiantes, que dessean perfeycionarse en la composición de la Mússica, ca. 1724-1738 (ed. facsímil: Bellaterra, Instituto “Josep Ricert i Matas”, 1990).

SANZ, G.: Instrucción de música sobre la guitarra española, Zaragoza, Herederos de Diego Dormer, 1674 (ed. facsímil: Zaragoza, Institución Fernando el Católico, 1979).

VAlls, F.: Mapa armónico práctico, Barcelona, 1742 (ejemplar de la Biblioteca de la Universidad de Barcelona, Ms. 783).

Bibliografía general:

Anglés, H. y Subira, J.: Catálogo musical de la Biblioteca Nacional de Madrid, Barcelona, C.S.I.C., 1946.

Araiz, A.: Historia de la Música Religiosa en España. Barcelona, Labor, 1942.

AshbeE, A.: The Harmonious Musick of John Jenkins: Volume One The Fantasias for Viols, Surbiton, Toccata Press, 1992.

BECKer, D.: "Lo hispánico y lo italiano en el teatro lírico español del siglo XVII", Actas del Congreso Internacional "España en la Música de Occidente" (Salamanca, 1985), Madrid, I.N.A.E.M., 1987, vol. I, pp. 371-384.

-: "Música de instrumentos, bailes y danzas en el teatro español del Siglo de Oro", Cuadernos de teatro clásico, 3, 1989, pp. 171-190.

BiAnConi, L.: Il Seicento (Storia della musica a cura della Società Italiana di Musicologia 4), Torino, EDT, 1982.

Bianconi, L. y Walker, T.: "Production, Consumption and Political Function of 17-Century Opera" (synoptic version), IMS Report of the twelfth congress Berkeley 1977, KasselBasel-London, Bärenreiter, 1981, pp. 680-711. 
ALGUNAS CONSIDERACIONES SOBRE LA MÚSICA PARA CONJUNTOS INSTRUMENTALES DEL SIGLO XVII ESPAÑOL

-: "Production, Consumption and Political Function of Seventeenth-Century Opera", Early Music History 4. Studies in medieval an early modern music edited by Ian Fenlon, Cambridge University Press, 1984, pp. 209-296.

Blasco, F. J.: La Música en Valencia. Apuntes históricos, Alicante, Imprenta de Sirvent y Sánchez, 1896.

Blume, F. y LaRue, J.: "Symphonie", Die Musik in Geschichte und Gegenwart, 1965.

Bonastre, F. : Música y parámetros de especulación, Madrid, Alpuerto, 1977.

-: "El Barroco: Notas en torno a la conciencia instrumental", La Música en el Barroco, Oviedo, Universidad de Oviedo, 1977, 109-112.

-: Nunc dimittis, a 11. Anònim, s. XVII, Quaderns de música històrica catalana, 4, Barcelona, Institut Josep Ricart i Matas, 1983.

-: "Tècnica instrumental a la polifonia catalana del segle XVI", en Actes del I Symposium de Musicologia Catalana. Joan Cererols i el seu temps, Barcelona, Institut d'Estudis Catalans, 1985, 77-93.

-: Francesc Soler-Obres Completes. Vol. III, 1. Completes a 15 (1686), Barcelona, Biblioteca de Catalunya, 1988.

Brito, M. C. de: Vilancicos do século XVII do mosteiro de Santa Cruz de Coimbra, Portugaliae Musica XLIII, Lisboa, Fundaçao Calouste Gulbenkian, 1983.

-: "Portuguese-Spanish musical relations during the 18th century", Actas del Congreso Internacional "España en la música de Occidente" (Salamanca, 1985), Madrid, INAEM, 1987, II, 133-137.

-: Opera in Portugal in the Eighteenth Century, Cambridge, Cambridge University Press, 1989. Brown, J. y Elliott, J. H.: Un palacio para el rey, Madrid, Alianza, 1981.

CALAhORRA, P.: La música en Zaragoza en los siglos XVI y XVII, I, Zaragoza, Institución Fernando el Católico, 1977.

-: "Dos inventarios de los siglos XVI y XVII en la colegial de Daroca y dos pequeñas crónicas darocenses", RSEdM, III, 1980, 33-75.

Calderón de la BArca, P.: La estatua de Prometeo, ed. de Margaret R. Greer con un estudio de la música por Louise K. Stein, Kassel, Reichenberger, 1986.

Carreras y Bulbena, J. R.: Carlos d'Austria y Elisabeth de Brunswich Wolfenbüttel a Barcelona y Girona, Barcelona, 1902.

Carreras López, J. J.: “«Conducir a Madrid estos moldes»: Producción, dramaturdia y recepción de la fiesta teatral Destinos vencen finezas (1698/1699)”, Revista de Musicología, XVIII, 1-2, 1995, 113-143.

CArse, A.: The History of Orchestration, New York, Dover, 1964 ( $1^{\text {a }}$ ed., 1925).

CAsares Rodicio, E.: La música en la Catedral de Oviedo, Oviedo, Universidad de Oviedo, 1980.

Catalan Algas, M. C. et al.: Libros de acuerdos y resoluciones del cabildo de la colegiata de Daroca (Zaragoza) (1529-1852), Zaragoza, Institución Fernando el Católico, 1990.

Climent, J.: "La música en Valencia durante el siglo XVII”, AnM, 21, 1966, 211-241. 
-: Fondos musicales de la región valenciana. I Catedral Metropolitana de Valencia, Valencia, Institución Alfonso el Magnánimo, 1979.

-: Fondos musicales de la región valenciana. II Real Colegio del Corpus Christi Patriarca, Valencia, Institución Alfonso el Magnánimo, 1984.

-: Fondos musicales de la región valenciana. IV Catedral de Orihuela, Valencia, Facultad de Teología San Vicente Ferrer, 1986.

-: Juan Bautista Comes. 1582?-1643. Obras en lengua romance I, II, III, IV, Valencia, Institución Alfonso el Magnánimo, 1977-79

Cotarelo y Mori, E.: Colección de entremeses, loas, bailes, jácaras y mojigangas desde fines del siglo XVI a mediados del XVIII, Madrid, Bailly-Baillière, 1911.

-: Orígenes y establecimiento de la ópera en España hasta 1800, Madrid, Tipografía de la Revista de Archivos, Bibliotecas y Museos, 1917.

-: Historia de la zarzuela, o sea el drama lírico en España, Madrid, Tipografía de la Revista de Archivos, Bibliotecas y Museos, 1934.

Cusick, S. G. y LARue, J.: "Sinfonia", The New Grove Dictionary, 1980.

D'ACCOnE, F. A.: The History of a Baroque Opera: Alessandro Scarlatti's "Gli equivoci nel sembiante”, Monographs in Musicology, $\mathrm{n}^{\circ}$. 3, New York, Pendragon Press, 1985.

D’Aulnoy, Mme.: Relación del viaje de España, Madrid, Akal, 1986 (según la edición de G. Mercadal)

Deleito y Piñuela, José: El rey se divierte, Madrid, Alianza, 1988.

DE MAEYER, R.: “Le «Geigenwerk» du Musée Instrumental de Bruxelles”, Instruments se musique espagnols du XVIe au XIXe siècle, Bruselas, Générale de Banque, 1985.

DíEz Borque, J. M.: La vida española en el Siglo de Oro según los extranjeros, Barcelona, Ediciones el Serbal, 1990.

Duron, J., ed.: Charpentier: David et Jonathas, París, CNRS, 1981.

ENGEL, H.: "Ouvertüre", $M G G, 1962$.

Ezquerro Esteban, A.: El músico aragonés Diego de Pontac, Zaragoza, Institución Fernando el Católico, 1991.

Ezquerro Esteban, A. y González Marín, L. A.: “Catálogo del fondo documental del siglo XVII del archivo musical de las catedrales de Zaragoza (Zac)", AnM, 46, 1991, 127-171.

FABRIS, D.: Andrea Falconieri Napoletano. Un liutista-compositore del Seicento, Roma, Edizioni Torre d'Orfeo, 1987.

FISHER, S. C.: "Overture", The New Grove Dictionary of Opera, 1992.

García Fraile, D.: Catálogo archivo de música de la Catedral de Salamanca, Cuenca, Inst. de Música Religiosa de la Dip. Prov. de Cuenca, 1981.

Georgiades, T.: Musica e linguaggio, Nápoles, Guida Editori, 1989 (1 ${ }^{\text {a }}$ ed. 1974).

González Marín, L. A.: Seis villancicos del Maestro de Capilla de El Pilar Don Joseph Ruiz. Samaniego (1661-1670), Zaragoza, Institución Fernando el Católico, 1987. 
ALgunas CONSIDERACIONES SOBRE LA MÚSICA PARA CONJUNTOS INSTRUMENTALES DEL SIGLO XVII ESPAÑOL

-: "Notas sobre la transposición en voces e instrumentos en la segunda mitad del siglo XVII: el repertorio de La Seo y El Pilar de Zaragoza", Recerca Musicològica, IX-X, 1988-1989, 303-325.

-: Música para los ministriles de El Pilar de Zaragoza (1671-1672), Zaragoza, Insitución Fernando el Católico, 1991.

—: "El órgano y el acompañamiento en la música española del Barroco", en Rolde, 58-59, 1991, 45-52.

-: "El teatro musical español del siglo XVII y sus posibilidades de restauración", en AnM, 48, 1993, 63-101.

-: F. Coppola-M. García Bustamante: "El robo de Proserpina” (Nápoles, 1678), Barcelona, CSIC, 1996.

-: Joseph Ruiz Samaniego: Lamentaciones del profeta Jeremías, Zaragoza, Institución Fernando el Católico (en prensa).

GonzÁlez VAlle, J. V.: "Música y Retórica: una nueva trayectoria de la «Ars musica» y la «Musica practica» a comienzos del Barroco", Revista de Musicología, X n³, 1987, pp. 811-841.

-: "Relación música-texto en la composición musical en castellano del siglo xVII", AnM, 47, 1992, 81-101.

Goñi Gaztambide, J.: La Capilla Musical de la Catedral de Pamplona en el siglo XviI, Pamplona, Capilla de Música de la Catedral, 1986.

Griffin, Thomas: The Late Baroque Serenata in Rome and Naples: A Documentary Study with Emphasis on Alessandro Scarlatti, Tesis Doctoral, University of California at Los Angeles, 1983.

Grout, D. J.: Alessandro Scarlatti: An Introduction to His Operas, Berkeley, University of California Press, 1979.

-: "Further Remarks on the Passacaglia and Ciaccona", JAMS, XXIII, 1970, 302.

-: "The Ripresa, the Ritornello, and the Passacaglia", JAMS, XXIV, 1971, 364-94.

-: "The Music in Italian Tablatures for the Five-course Spanish Guitar", Journal of the Lute Society of America, IV, 1971, 21.

-: "Chaconne", The New Grove Dictionary, 1980.

-: "Passacaglia", The New Grove Dictionary, 1980.

-: "Ripresa", The New Grove Dictionary, 1980.

Hutchings, A.: "Ritornello", The New Grove Dictionary, 1980.

JAMBOU, L.: "Documentos relativos a los músicos de la segunda mitad del siglo XVII de las Capillas Reales y Villa y Corte de Madrid, sacados de su Archivo de Protocolos", Revista de Musicología, 12 (2), 1989, 469-514.

KASTNER, M. S.: Sette pezzi per arpa dei secoli XVII e XVIII tratti da antichi manoscritti spagnoli e portoghesi, Milán, Edizioni Suvini Zerboni, 1986.

LAIRD, P. R.: The Villancico Repertory at San Lorenzo el Real del Escorial, c.1630-c.1715. Tesis doctoral, University of North Carolina, Chapel Hill, 1986. 
—: "Diego de Torrijos and the Villancico at San Lorenzo del Escorial 1669-1691", en Revista de Musicología 12/2, 1989.

-: "The Villancicos of Matías Juan de Veana as a model for the study of the dissemination of the Baroque Villancico", en AnM XLIV, 1989, pp. 115-136.

Lemaitre, E., ed.: Charpentier, M. A.: Médée, París, CNRS, 1987.

LEON Tello, F. J.: La teoría española de la música en los siglos XVI y XVII, Madrid, C.S.I.C., 1974.

Livingston, H.: The Italian Overture from A. Scarlatti to Mozart, diss., U. of North Carolina, 1952.

Lolo, B.: La música en la Real Capilla de Madrid: José de Torres y Martínez Bravo (h. 16701738), Madrid, Universidad Autónoma, 1988.

López-Calo, J.: Catálogo musical del archivo de la Santa Iglesia Catedral de Santiago, Cuenca, Inst. de Música Religiosa de Cuenca, 1972.

-: "La música religiosa en el barroco español. Orígenes y características generales", La Música en el Barroco, Oviedo, Universidad de Oviedo 1977, 147-189.

-: Catálogo del archivo de música de la catedral de Avila, Santiago de Compostela, S.E.M., 1978.

-: La música en la catedral de Palencia. Vol. I Catalogo musical. Actas Capitulares (14131684), Palencia, Inst. Tello Tellez de Meneses, 1980.

-: La música en la catedral de Palencia. Actas capitulares. Vol. II, Palencia, Institución Tello Tellez de Meneses, 1981.

—: Historia de la música española. 3. Siglo XVII, Madrid, Alianza, 1983.

- : La música en la catedral de Santo Domingo de la Calzada, Logroño, Gobierno de La Rioja, 1988.

—: La música en la catedral de Segovia, I y II, Segovia, Diputación Provincial, 1988-1989.

- : Documentario musical de la catedral de Segovia, I, Santiago de Compostela, Universidad de Santiago, 1990.

- Obras musicales de fray José de Vaquedano Santiago de Compostela, Música en Compostela, 1990.

LOZANO GONZÁlEZ, A.: La música popular, religiosa y dramática en Zaragoza desde el siglo XVI hasta nuestros días, Zaragoza, Tip. de Julián Sanz y Navarro, 1895.

Llorden, A.: "Notas históricas de los maestros de capilla en la catedral de Málaga", AnM, 20, 1965, 105-135.

-: "Notas históricas de los maestros organistas de la Catedral de Málaga (1585-1799) (Segunda parte)", AnM, 23, 1968, 157-189.

Martín Moreno, A.: El padre Feijoo y las ideologías musicales del XVIII en España, Orense, Instituto de Estudios Orensanos "Padre Feijoo", 1976.

-: "La música teatral del siglo XVII español", La Música en el Barroco, Oviedo, Universidad de Oviedo, 1977, pp. 125-146. 
AlgunAS CONSIDERACIONES SOBRE LA MÚSICA PARA CONJUNTOS INSTRUMENTALES DEL SIGLO XVII ESPAÑOL

—: Sebastián Durón-José de Cañizares: «Salir el Amor del mundo», zarzuela en dos jornadas, Málaga, Sociedad Española de Musicología, 1979.

-: Historia de la música andaluza, Sevilla, Editoriales Andaluzas Unidas, 1985.

-: Historia de la música española. 4. Siglo XVIII, Madrid, Alianza, 1985.

Martínez Millán, M.: Historia musical de la catedral de Cuenca. Cuenca, Dip. Prov. de Cuenca, 1988.

Maura Gamazo, G.: Carlos II y su corte, Madrid, Librería de F. Beltrán, 1911-1915.

-.: Vida y reinado de Carlos II, Madrid, Espasa Calpe, 1942.

Maura, Duque de y González-Amezua, A.: Fantasías y realidades del viaje a Madrid de la condesa D'Aulnoy, Madrid, Calleja, s. f.

Mayer-Brown, H.: Sixteenth-Century Instrumentation: The Music for the Florentine Intermedii, Musicological Studies and Documents, 30, American Institute of Musicology, 1973.

MitjanA, R.: Historia de la música en España (traducción de "La Musique en Espagne", Encyclopédie de la Musique et Dictionaire du Conservatoire dirigida por A. Lavignac, Paris, Librairie Ch. Delagrave, 1913 y ss., vol. IV, pp. 1.913-2.351), Madrid, I.N.A.E.M., 1993.

Murata, M.: Operas for the Papal Court 1631-1668, Ann-Arbor, UMI, 1981.

Navarro Gonzálo, R.: Catálogo musical del archivo de la Santa Catedral Basílica de Cuenca, Cuenca, Instituto de Música Religiosa, 1973.

Newman, J.: Jean-Baptiste de Lully and his Tragédies Lyriques, Studies in Musicology, $\mathrm{n}^{\circ}$. 1, UMI Research Press, 1979.

Newman, W. S.: The Sonata in the Baroque Era, New York, Norton, ${ }^{4} 1983$.

Osthoff, W.: "Die frühesten Erscheinungsformen der Passacaglia in der italienischen Musik des 17. Jahrhunderts", Congresso internazionale di musiche popolari mediterranee: Palermo, 1954, 275.

Pagano, R. y Bianchi, L.: Alessandro Scarlatti, Turín, ERI, 1972.

PAVIA I SiMÓ, J.: La música a la catedral de Barcelona durant el segle XVII, Barcelona, Fundació Salvador Vives Casajuana, 1986.

Pedrell, F.: Catàlech de la Biblioteca Musical de la Diputació de Barcelona, Barcelona, Diputación de Barcelona, 1908.

Phillips, E. V., ed.: The Collected Works of Henry Butler, Madison, A-R Editions, Inc.

PIEdra, J.: "Maestros de capilla del Real Colegio de Corpus Christi (Patriarca) (1662-1822)", AnM, 23, 1968, 61-127.

Prunières, H.: Oeuvres complètes de J.-B. Lully (1632-1687) publiées sous la Direction de Henry Prunières. Les Opéras, New York, Broude Brothers Limited, 1966 (tomos I y II) y 1971 (tomo III).

Querol, M.: Cantatas y canciones para voz solista e instrumentos (1640-1760), Barcelona, C.S.I.C., 1973.

_-: "El archivo de música de la colegial de Jerez de la Frontera", AnM, 30, 1975, 167-180.

-: Teatro musical de Calderón (Música barroca española, vol. VI), Barcelona, C.S.I.C., 1981. 
—: Villancicos polifónicos del siglo XVII (Música barroca española, vol. III), Barcelona, C.S.I.C., 1982.

REICHERT, G.: "Chaconne”, $M G G, 1952$.

Roberts, J. H., ed.: Handel Sources. Materials for the Study of Handel's Borrowing, New York, Garland, 1986, IX vols.

Robledo, L.: "Los cánones enigmáticos de Juan del Vado", Poesía, 9, 1980, 91-104.

-: "Vihuelas de arco y violones en la corte de Felipe III", Actas del Congreso Internacional «España en la Música de Occidente» (Salamanca, 1985), Madrid, I.N.A.E.M., 1987, vol. II, pp. 63-76.

—: Juan Blas de Castro (ca. 1561-1631). Vida y obra musical, Zaragoza, Institución Fernando el Católico, 1989.

Rolland, R.: Les origines du théâtre lyrique moderne. Histoire de l'Opera en Europe avant Lully et Scarlatti, Paris, 1895, reed. Ginebra, Slatkine Reprints, 1971.

Rubio, S.: Catálogo del Archivo de Música de San Lorenzo El Real de El Escorial, Cuenca, Instituto de Música Religiosa, 1976.

Rubio Piqueras, F.: "Archivo Musical de la Catedral de Toledo primada de las Españas; Apéndice", en TSM, 1928, p.78.

Ruiz DE ElvirA, I., coord.: Catálogo de Villancicos de la Biblioteca Nacional. Siglo XVII, Madrid, Ministerio de Cultura, 1992.

Russell, C. H.: "Imported Influences in 17th and 18th Century Guitar Music in Spain", Actas del Congreso Internacional "España en la música de Occidente" (Salamanca, 1985), Madrid, INAEM, 1987, I, 385ss.

Shergold, N. D. y VAREY, John E.: Repesentaciones palaciegas: 1603-1699. Estudio y documentos, London, Tamesis Books, 1982.

Solar Quintes, N. A.: "Músicos de Mariana de Neoburgo y de la Real Capilla de Nápoles", Anuario Musical, XI, 1956, pp. 1-29.

Stein, L. K.: "La plática de los dioses", en P. Calderón DE la BARCA: La estatua de Prometeo, ed. al cuidado de Margaret R. Greer, Kassel, Reichenberger, 1986, 13-92.

-: Music in the Seventeenth-Century Spanish secular Theater, Tesis Doctoral, Universidad de Chicago, 1987.

-: Songs of Mortals, Dialogues of the Gods. Music and Theatre in Seventeenth-Century Spain, Oxford, Clarendon Press, 1993.

Stevenson, R.: Renaissance and Baroque musical Sources in the Americas, Washington, 1970.

-: "Espectáculos musicales en la España del siglo XVII", Revista Musical Chilena, 27, 1972, pp. 3-44.

-: Foundations of New World Opera, Lima, Ediciones Cultura, 1973.

-: Villancicos portugueses (Portugalice Musica XXIX), Lisboa, Fundaçao Calouste Gulbenkian, 1976, pp. XLIII-XLIX.

—: "Hispanic American Music Treasury", en Inter-American Music Review, VI, 2, 1985.

SubirA, J.: La música en la Casa de Alba, Madrid, Sucesores de Rivadeneyra, 1927. 
-: Celos aun del aire matan, ópera del siglo XVII. Texto de Calderón y música de Juan Hidalgo,

Barcelona, Institut d'Estudis Catalans-Biblioteca de Catalunya, 1933.

- Historia de la música teatral en España, Barcelona, Labor, 1945.

- La ópera en los teatros de Barcelona. Estudio histórico cronológico desde el siglo XVIII al XX, Barcelona, Librería Millá, 1946, 2 vols.

-: Historia de la música española e hispanoamericana, Barcelona, Salvat, 1953.

-: Temas musicales madrileños, Madrid, C.S.I.C., 1970.

-: El teatro español en su siglo de oro, Barcelona, Planeta, 1969.

TEMPERley, N.: “Overture”, The New Grove Dictionary, 1980.

TODA I GüEll, E.: Bibliografia Espanyola d'Italia dels origens de la imprempta fins a l'any 1900, Barcelona, Casa Vidal-Güell, 1927-1931.

TORCHI, L.: La musica strumentale in Italia nei secoli XVI, XVII e XVIII, Rivista Musicale Italiana, vol. IV-VIII, reed. Bolonia, Arnaldo Forni, 1980.

VARey, J. E. y Shergiold, N. D.: Comedias en Madrid: 1603-1709. Repertorio y estudio bibliográfico, London, Tamesis Books, 1989.

Velez de Guevara, J.: Los celos hacen estrellas (ed. al cuidado de J. E. Varey y N. D. Shergold, con una transcripción de la música de J. Sage), London, Tamesis Books, 1970.

Villanueva Abelairas, C.: Las Lamentaciones de Semana Santa de Fray José de Vaquedano, Santiago de Compostela, Universidad de Santiago de Compostela, 1990.

VON Fischer, K.: "Passacaglia", $M G G, 1962$.

WALker, T.: "Ciaccona and Passacaglia: Remarks on Their Origin and Early History", JAMS, XXI, 1968, pp. 300-320.

WiBerg, J. L.: «Opera Scenica, deduzida de la Guerra de los Gigantes» by Sebastián Durón, an edition and commentary, Ann Arbor, UMI, 1985.

WoOdFIELD, I. : "El primer conde de Sandwich, una interpretación de William Lawes en España y los orígenes del pardessus de viole", Musica Antiqua, 6, 1987, 6-7. 


\section{Ejemplos musicales}
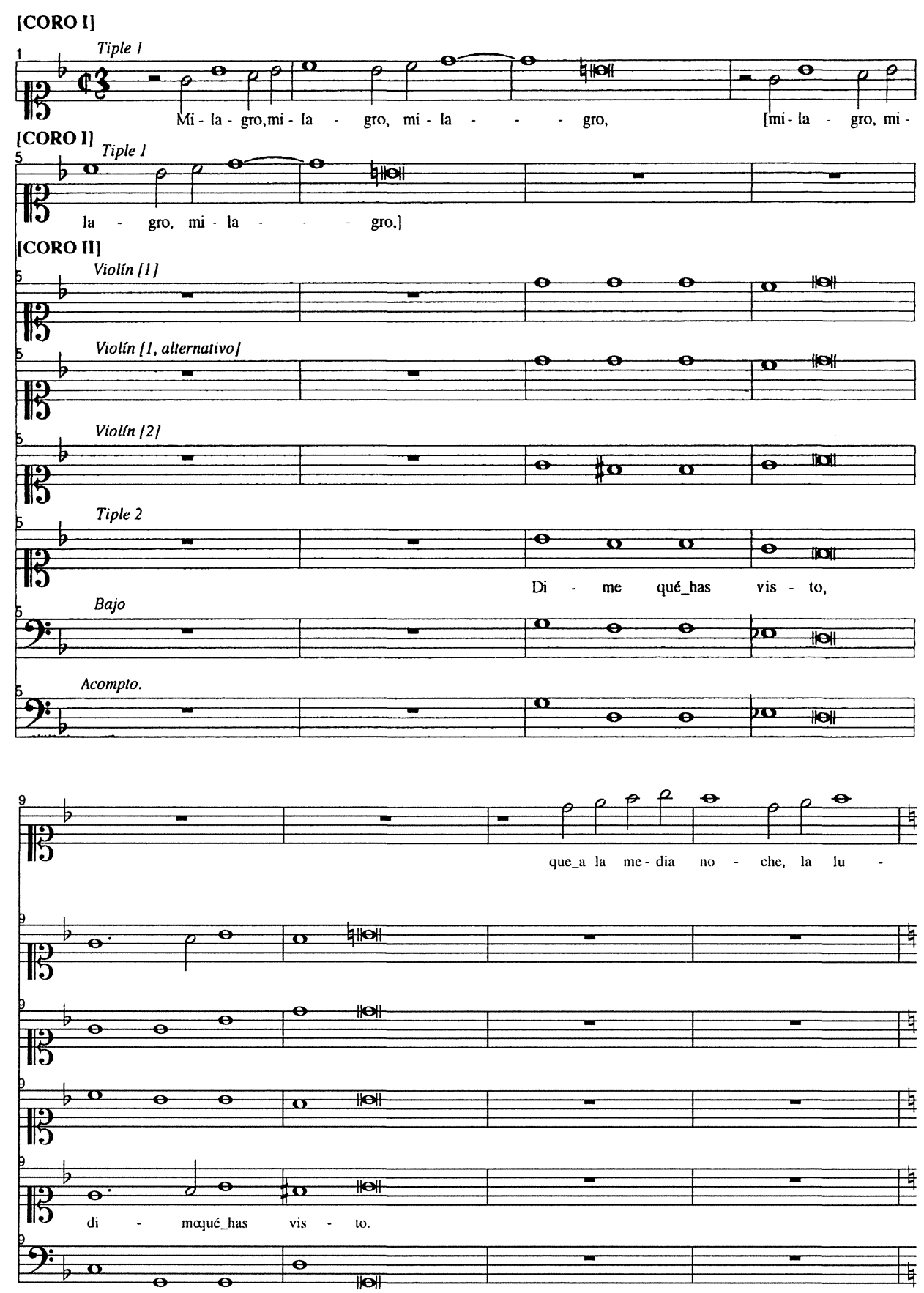

1. Pedro Ximénez de LunA: Milagro, milagro, villancico de Reyes (E:Zac B-27/449), entrada. 

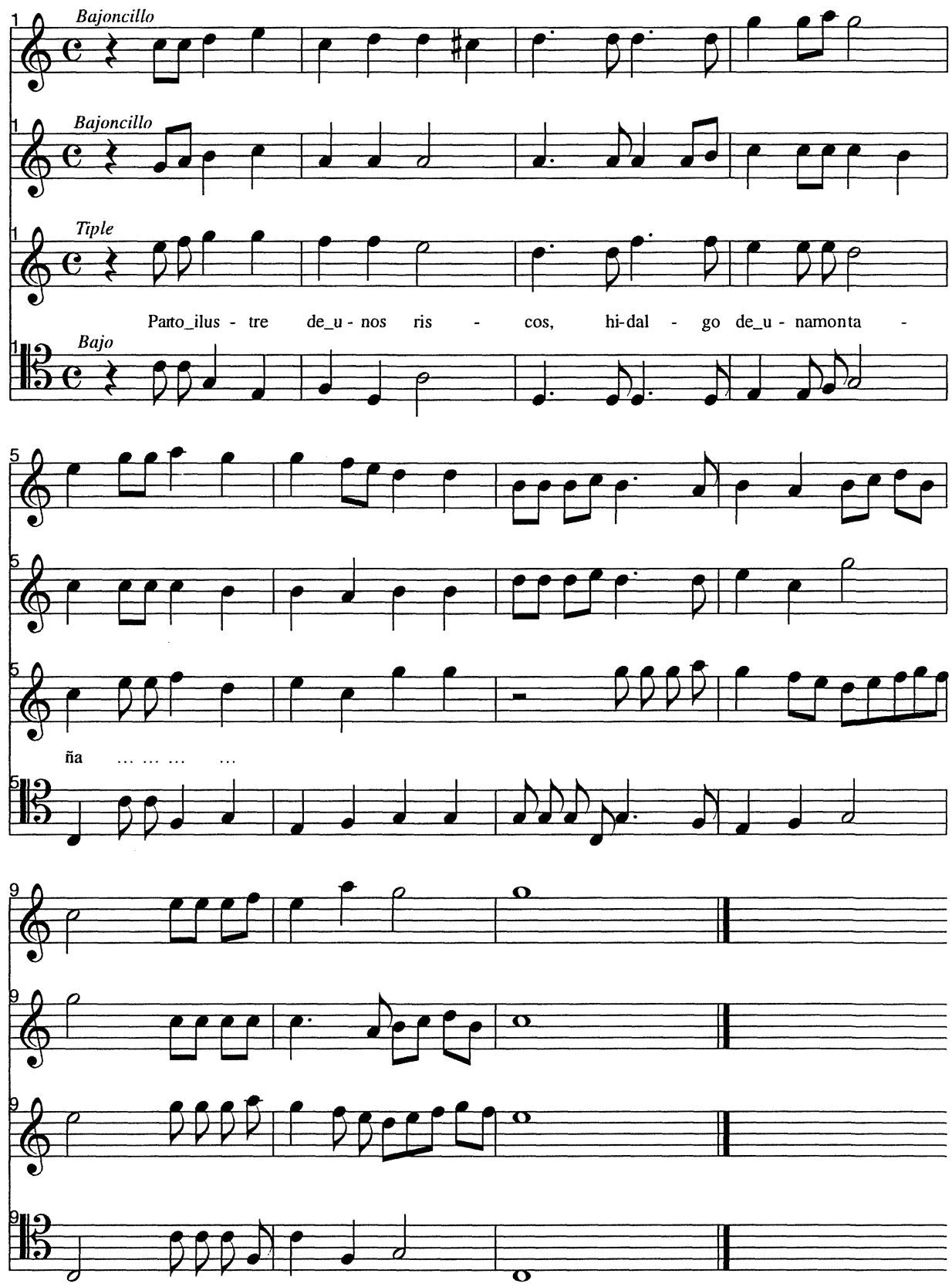

2. Urbán de VARGAS: Muera, muera, villancico a San Juan Bautista (E:Zac B-3/48), coplas. 

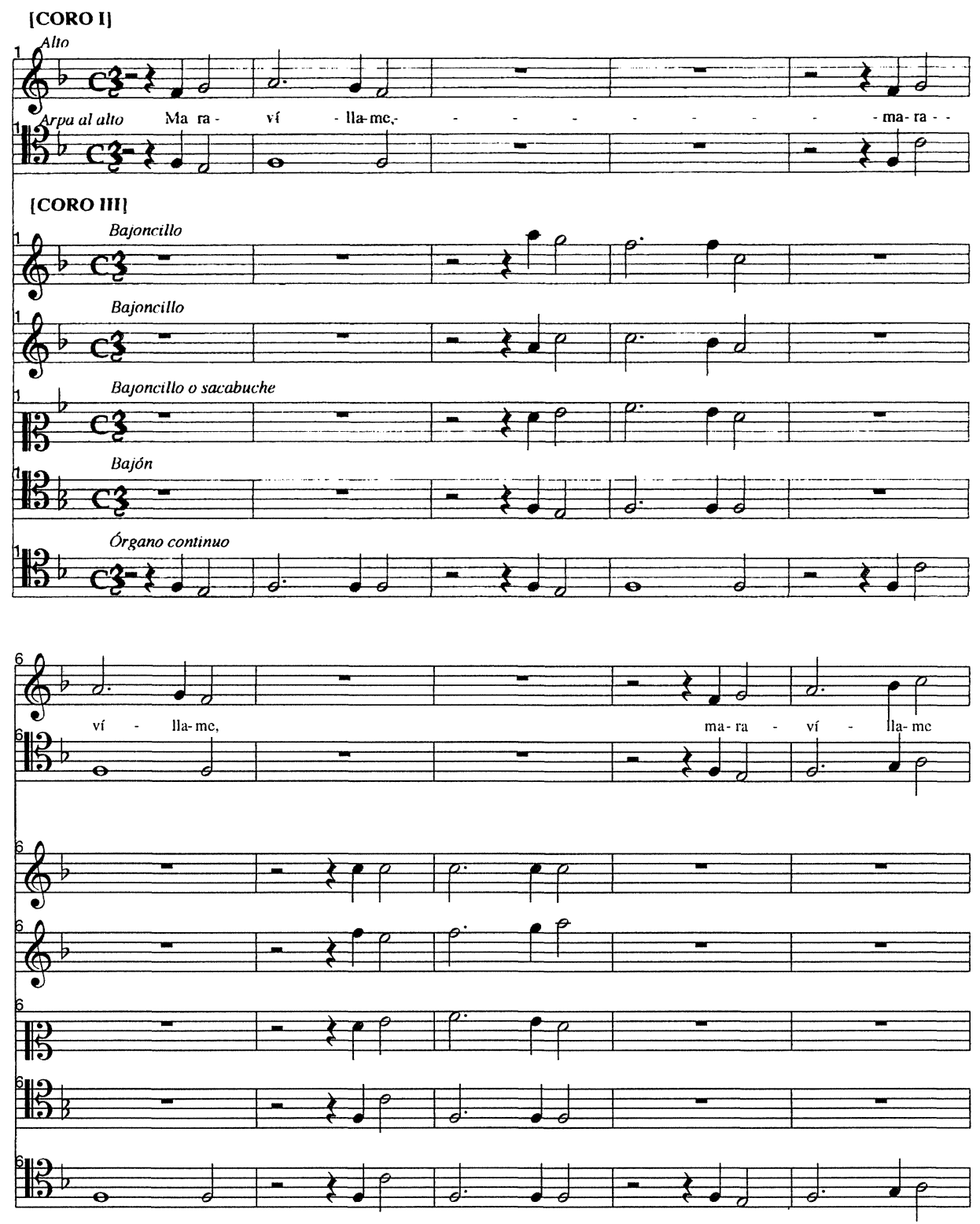

3. Gregorio López: Maravíllame novedades, villancico de Navidad (E:Zac B-30/474), introducción. 

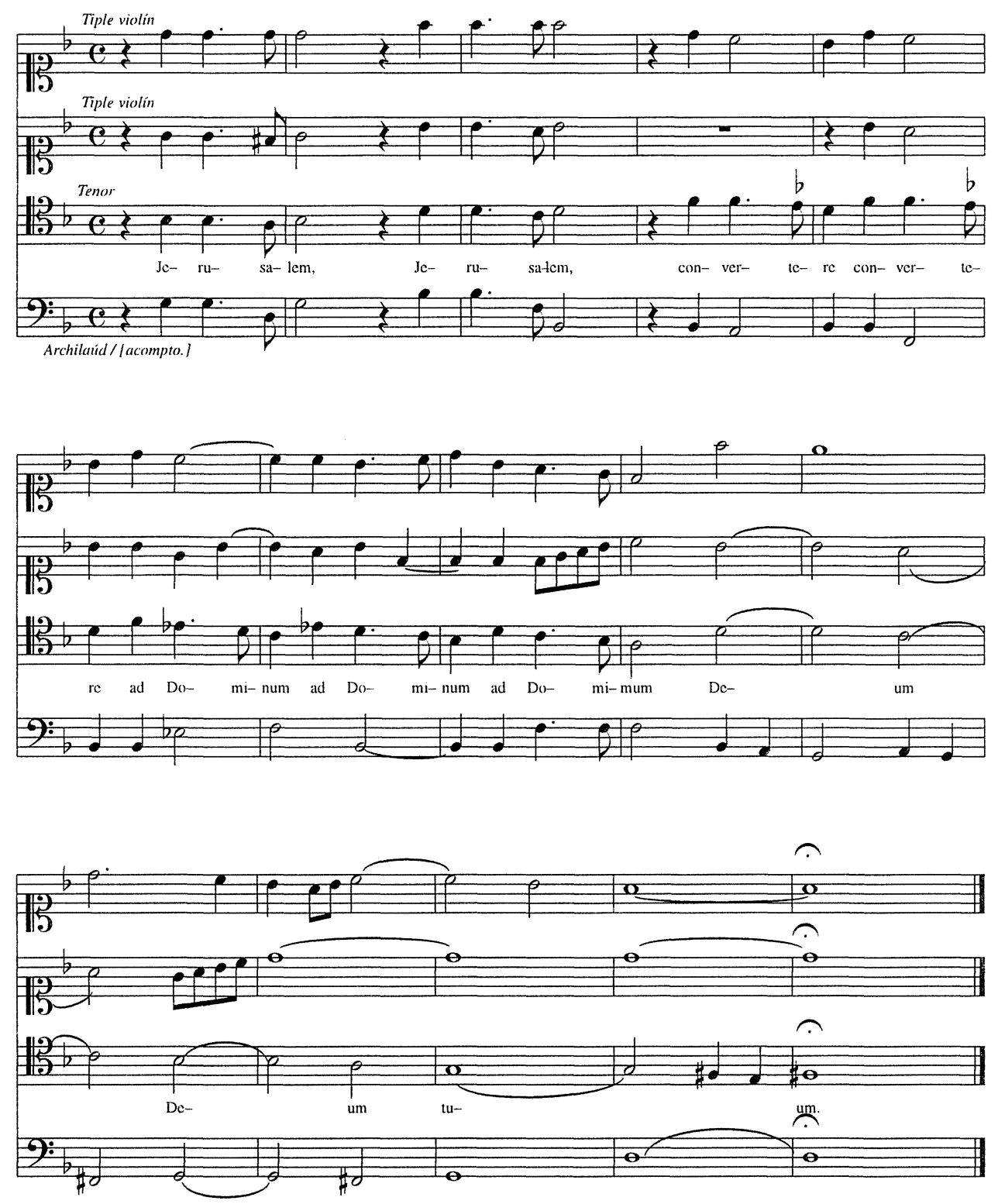

4. Joseph Ruiz Samaniego: Lamentación $2^{a}$ Feria VI

(E:Zac B-44/669), final. 


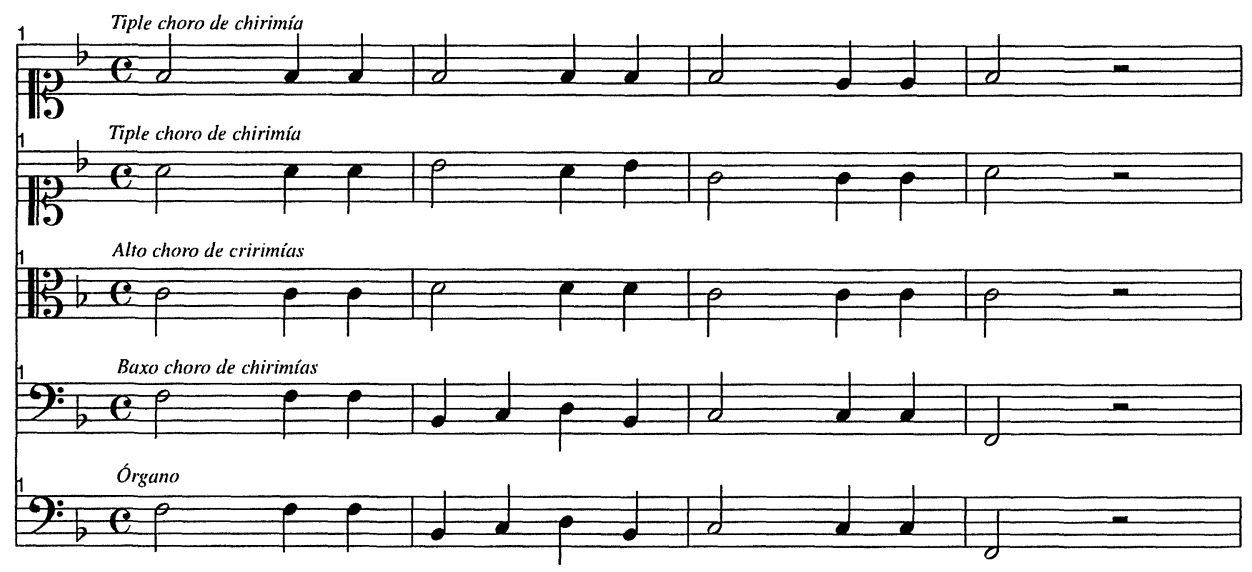

5. Urbán de VARGAS: Muera, muera, villancico a San Juan Bautista (E:Zac B-3/48), pasacalle.

[CORO III]

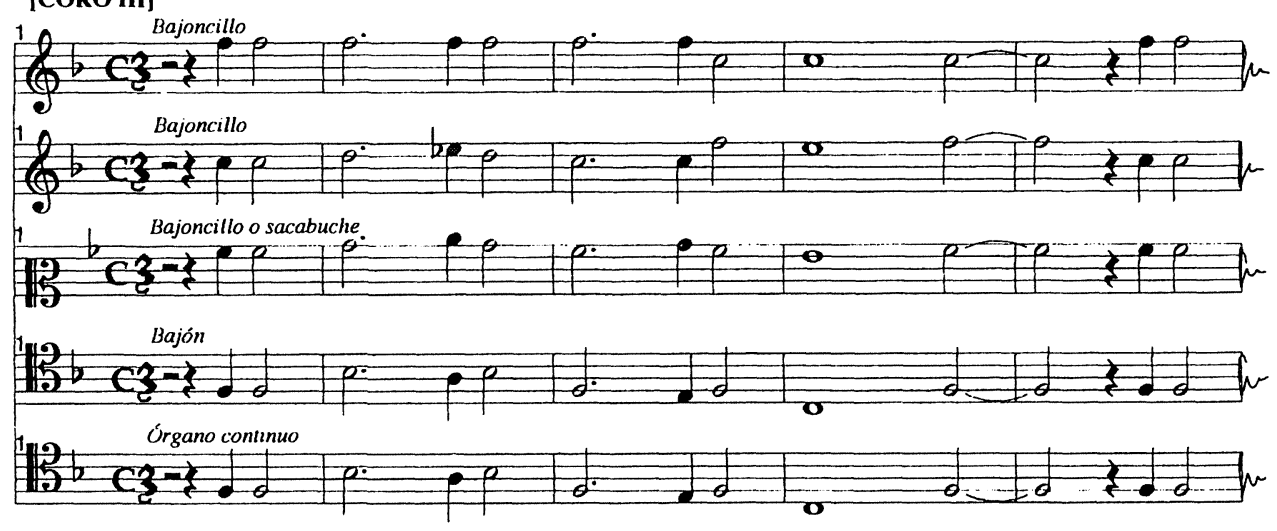

6. Gregorio LóPEZ: Maravíllame novedades, villancico de Navidad (E:Zac B-30/474), pasacalle. 

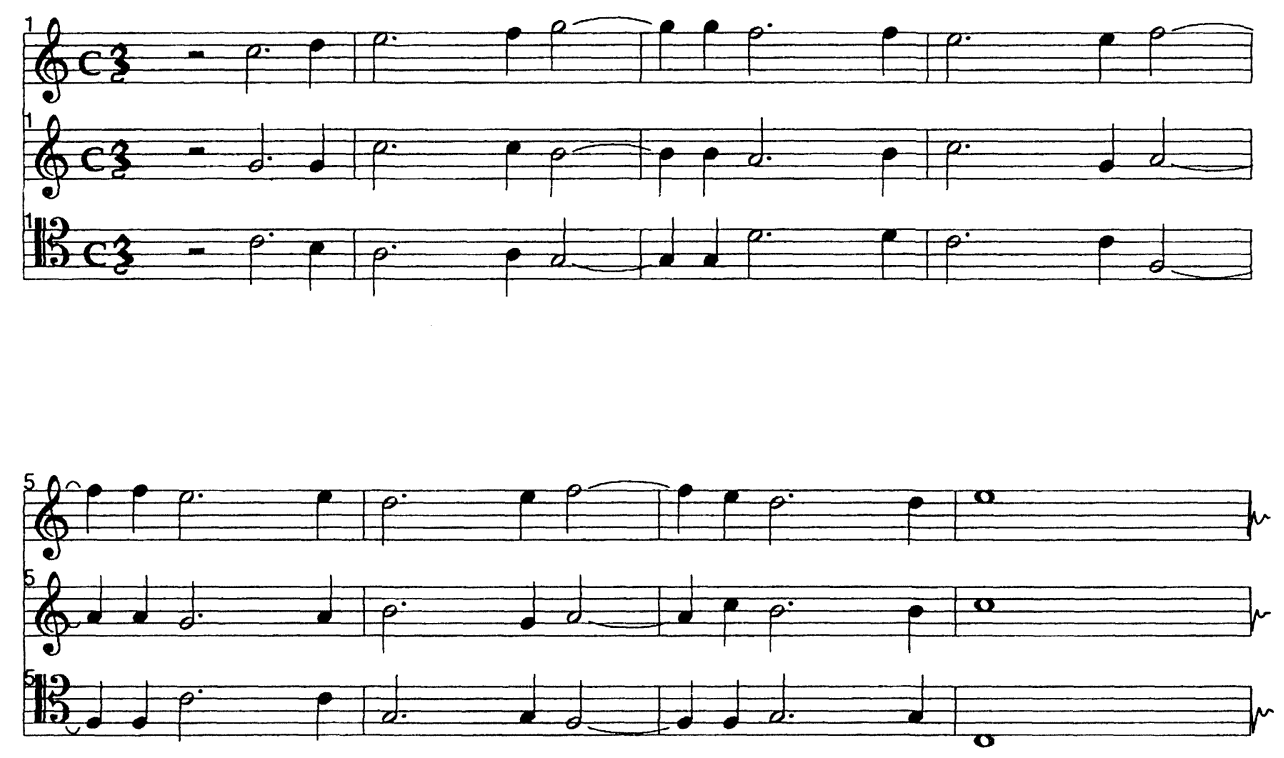

7. Juan PÉrez Roldán: Por mostrarnos a su hijo, villancico a la Asunción (E:Zac B-9/171), pasacalle. 

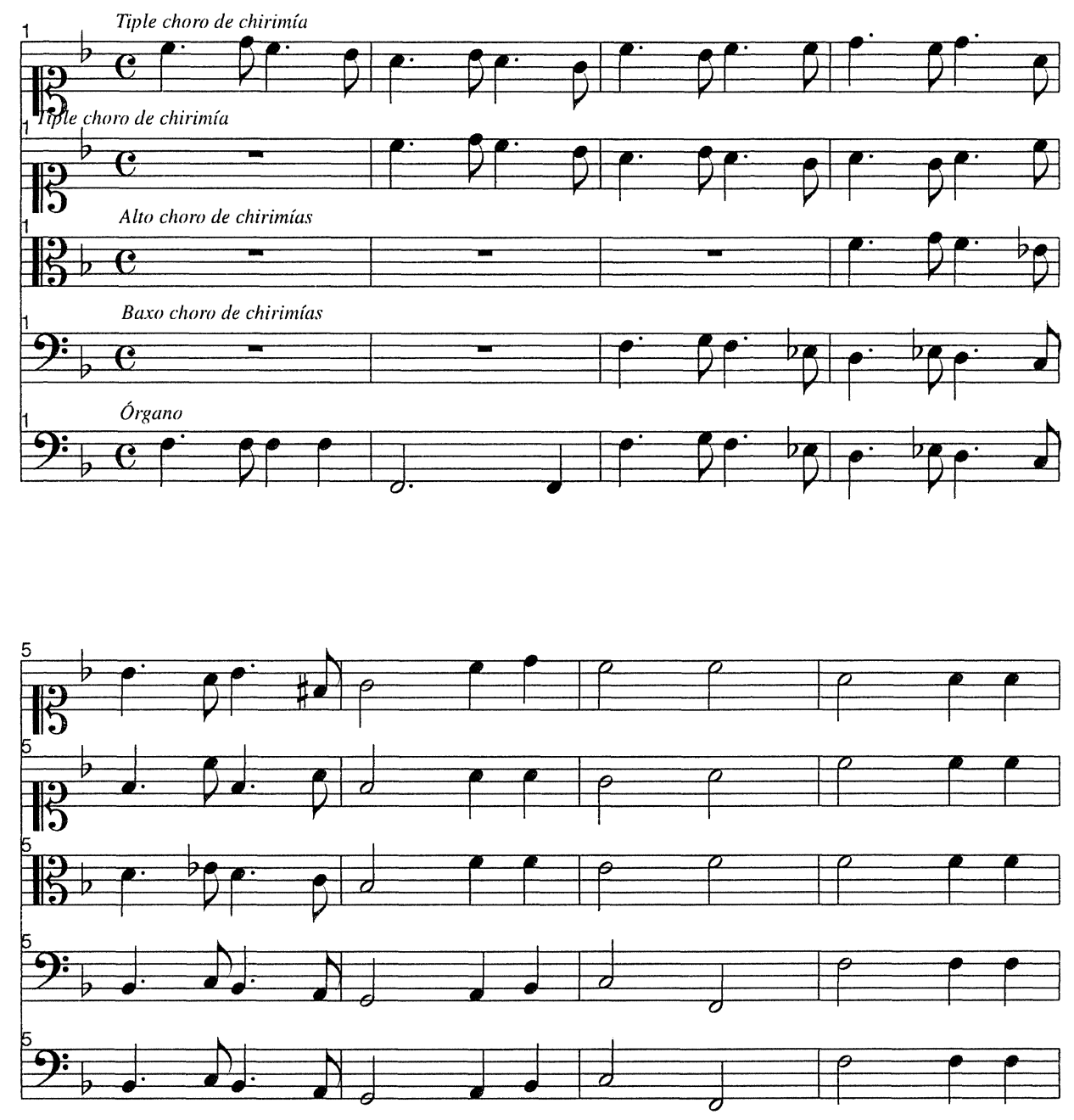

8. Urbán de VARGAS: Muera, muera, villancico a San Juan Bautista (E:Zac B-3/48), comienzo de la responsión. 
Tocata de chirimías
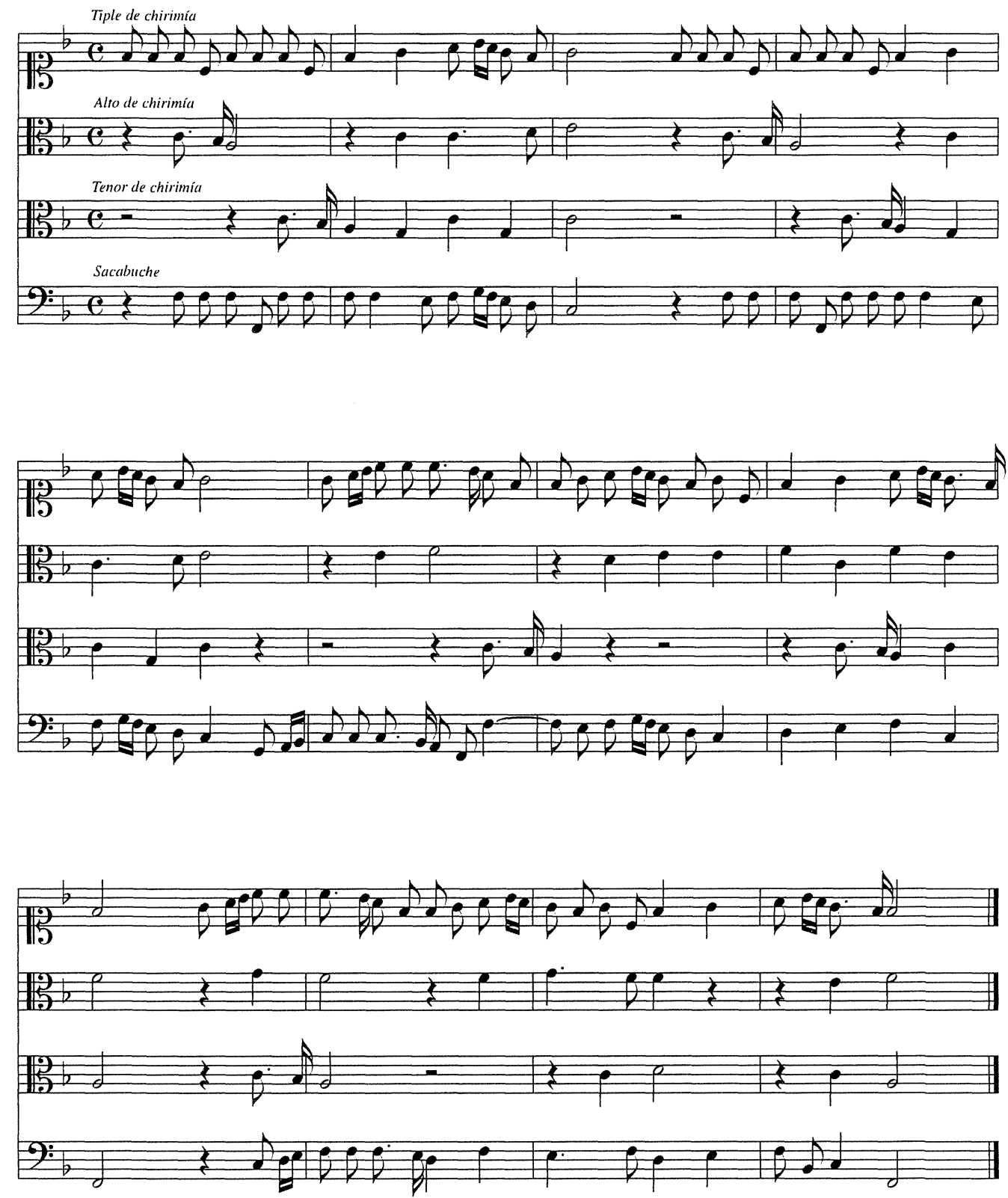

9. Joseph RuIz SAmAnIEGo: Ya ríe el alba, villancico de Reyes de 1665 (E:Zac B-46/693), tocata de chirimías. 